\title{
PEIRCE'S EVOLUTIONARY PRAGMATIC IDEALISM
}

\begin{abstract}
This article is dedicated to the memory of Edward Carter Moore (1917-1993) - for his many contributions to Peirce scholarship. Ed wrote on Peirce, James, and Dewey. As Dean of the Graduate School of the University of Massachusetts he founded the Transactions of the Peirce Society. In 1973 he became Dean of the Faculties and Professor of Philosophy at Indiana University/Purdue University at Indianapolis, in charge of academic matters of that newly organized institution. In that role he founded and directed the new chronological edition of Peirce's writings.
\end{abstract}

\begin{abstract}
In this paper I synthesize a unified system out of Peirce's life work, and name it "Peirce's Evolutionary Pragmatic Idealism". Peirce developed this philosophy in four stages:

(I) His $1868-69$ theory that cognition is a continuous and infinite social semiotic process, in which Man is a sign.

(II) His Popular Science Monthly pragmatism and frequency theory of probabilistic induction.

(III) His 1891-93 cosmic evolutionism of Tychism, Synechism, and Agapism.

(IV) Pragmaticism: The doctrine of real potentialities ("would-be's"), and Peirce's pragmatic program for developing concrete reasonableness.

Peirce's evolutionary conception of the cosmos is pantheistic, and he constructed it to reconcile religion with Darwinian evolution.
\end{abstract}

\section{PEIRCE'S PHILOSOPHIC SYSTEM*}

Peirce said that he never achieved the system of philosophy that he sought, but his writings actually do contain (in an evolutionary and spread-out manner) a grand system of philosophy. This system was a highly original form of idealism, combining his early semiotic idealism, his pragmatism, and his novel theory of cosmic evolution.

As Peirce recognized, his pragmatic idealism resembled the absolute idealism of G. W. F. Hegel (1770-1831). Both were an outgrowth from Immanuel Kant's Critique of Pure Reason, Peirce's directly and Hegel's via

Synthese 106: 323-372, 1996.

(c) 1996 Kluwer Academic Publishers. Printed in the Netherlands. 
Johann Fichte and F. W. J. Schelling. But hardly any of Peirce's contemporaries recognized that Peirce was developing a form of absolute idealism, the absolute idealist Josiah Royce being an exception.

Peirce was not very influential in his own time. He never found a regular academic appointment. Intellectually, his writings were too technical and presupposed far too much science and logic for philosophers and others who might otherwise have been interested in them. Moreover, Peirce was a difficult person. He was often irresponsible; moreover, his life-style clashed sharply with the culture and the people in power. As a consequence, he never held a philosophical pulpit long enough to spread his message. See Joseph Brent's Charles Sanders Peirce-A Life (1993). This is an excellent biography, the first presentation actually to explain Peirce's exceptional behavior and the failure of his professional and commercial ambitions.

In this paper I will formulate the philosophy I am calling "Peirce's evolutionary pragmatic idealism". As I have edited, studied, and taught Peirce over the years I have come to understand his idealistic system and to appreciate its originality, depth, and comprehensiveness. Peirce's philosophical evolutionism was the first to take account of the sciences of astronomical evolution, physics, chemistry, Darwinian evolution, and psychology. It is based on his novel semiotics and on his tripartite logic of discovery, induction, and deduction; and it draws on both the history of philosophy and human culture.

Peirce was one of the creators of the logic of relations, the extension of classical logic and Boolean algebra that was needed for a full system of symbolic logic. His own writings are relational in having so many interconnections, and so the best way to present his philosophy would be as a relational structure, or database (Moore and Burks 1992, p. 99). And because Peirce's writings are relational we will sometimes repeat a quotation when the context is different.

Peirce's own philosophical evolution began as a reaction to the limits of Kant's philosophy of pure and practical reason, and proceeded through four main Stages: (I) the logic of relations, semiotics, and the nature of inquiry, (II) scientific inquiry and pragmatism, (III) cosmic evolution and learning, and (IV) the final formulation of pragmatism (which he called pragmaticism). I will list Peirce's most important publications of each stage and use their dates to place the stage (Burks 1946b, 1951b, 1964; 1977, secs. $4.2 \& 8.4 ; 1990$, sec. 4.1 ). 
Each stage describes an infinite goal-directed evolutionary process that converges on the real, and the four stages together constitute a philosophic progression. I also find that the language, concepts, and theses of each stage can be reformulated so as to incorporate those of the prior stages.

(Stage I) From 1867-71 Peirce published a series on logic in the Proceedings of the American Academy of Arts and Sciences, a series on intuitive knowledge and semiotics in Volume II of the Journal of Speculative Philosophy, and his reviews of the work of Venn and Berkeley. Peirce introduced his three categories of Quality-Relation-Representation (later to become First-Second-Third) and distinguished the corresponding kinds of signs (icon-index-symbol) and of arguments (abductioninduction-deduction). (Abduction, which Peirce originally called "hypothesis", is the logic of discovery. Note that the three prefixes to "duction" are $\mathrm{ab}=$ "away from", in = "inward", and de = "undoing".)

Peirce also used his understanding of the logic of relations and of Darwinian evolution to work his way from Kant's individualistic categories to a communal limit theory of communication, inquiry, knowledge, and reality. He said that cognition involves a continuous semiotic-inference process, and he defined reality in terms of the ultimate result of inquiry:

And what do we mean by the real? ... The real, then, is that which, sooner or later, information and reasoning would finally result in, and which is therefore independent of the vagaries of me and you. Thus, the very origin of the conception of reality shows that this conception essentially involves the notion of a COMMUNITY, without definite limits, and capable of a definite increase in knowledge. [5.311]

We will discuss this quotation further in the section "Man's Glassy Essence". [The reference 5.311 is to paragraph 511 of volume 5 of the Collected Papers of Charles Sanders Peirce, volumes 1-6 edited by Charles Hartshorne and Paul Weiss, volumes $7-8$ by the writer.]

(Stage II) In 1877-78 Peirce published a series of six papers in the Popular Science Monthly under the general title "Illustrations of the Logic of Science". The most important was "How to Make Our Ideas Clear", the classic statement of pragmatism. In these articles Peirce approached learning, knowledge, and reality from the perspective of the community of scientific investigators. He transformed his limit theory of inquiry of the first stage into pragmatism, giving the first justification of induction in terms of frequency probabilities (Burks 1977, sec. 3.4.2).

In 1879 he published a short "Note on the Theory of the Economy of Research" [7.139-157; cf. 7.158-161]. This was a mathematical treatment of the relation of the cost of precise measurement to the resultant reduction in the probable error of the results. He used as an example his own measurements of the force of gravity by swinging a pendulum and measuring 
its period of oscillation. This was a classic paper on the logical design of experiments.

In these first two stages Peirce treated inference as a human learning and evidencing process, while in the next two stages he generalized from it to a cosmic evolutionary growth process. This big generalization occurred at about the same time that Peirce was fired from his professorship at Johns Hopkins University and then lost his only regular position, the job at the Coast Survey that his father had gotten for him.

(Stage III) The central publications of this stage were Peirce's 1891-93 series on metaphysics in The Monist:

The Architecture of Theories (6.7-34)

The Doctrine of Necessity Examined (6.35-65)

The Law of Mind (6.102-165)

Man's Glassy Essence (6.238-271)

Evolutionary Love (6.287-317).

These papers develop Peirce's grand law of cosmic evolution, the core of his evolutionary pragmatic idealism.

Peirce arrived at his law of cosmic evolution by extending his logical categories of First-Second-Third to new realms. In psychology, feelings and sense-experiences are Firsts; feelings of resistance and interaction and acts of will are Seconds; habits, reasoning, and human intentional goal-directedness are Thirds. In metaphysics, monadic properties are First, dyadic relations are Seconds, and causal laws are Thirds.

Now, in cosmology, First, Second, and Third become aspects of the evolutionary history of the universe. Tychism, the doctrine that the laws of nature and mind are probabilistic, is First, Synechism, the doctrine that the evolution of things, laws, systems, and knowledge is strictly continuous, is Second. By "continuity" Peirce meant the mathematical sense of that term. Agapism, the doctrine that final causes guide evolution toward a supreme value goal, is Third. Peirce used these broadened categories as a basis for a radically new evolutionary teleological cosmology. Evolution begins as an original chaos of bare feelings and gradually evolves the objects and laws of astronomy, physics, chemistry, biology, humanity, and culture.

Thus Peirce's grand law of cosmic evolution has three aspects: Tychism (chance), Synechism (continuity), and Agapism (love). When we wish to emphasize these aspects we will use the name Tychism-Synechism-Agapism for Peirce's grand law.

Note that the evolutions depicted in Stages I and II of Peirce's thought become the human-history segment of this cosmic telelogical evolutionary 
process. Peirce recognized the similarity of this segment of cosmic evolution to the historical dialectic process described by Hegel, and for this reason called his own account of evolution

objective logic because that conveys the correct idea that it is like Hegel's logic. [1.444]

In his Monist series he called his tychism-synechism-agapism theory "objective idealism":

The one intelligible theory of the universe is that of objective idealism, that matter is effete mind, inveterate habits become physical laws. [6.25; cf. 6.163]

Thus for Peirce a seemingly universal physical law is the limiting case of a statistical law, the case in which the probability of the effect following the cause has evolved to be very close to 1 .

But Peirce also recognized the profound differences between his cosmic evolutionism and Hegel's much more limited dialectic evolutionism:

... my philosophy resuscitates Hegel, though in a strange costume. [1.42, italics added]

Peirce's evolutionary process from chaos through physics, chemistry, and biology to human culture and on to the future is indeed more dynamic and certainly much more inclusive than Hegel's dialectical rational evolution of iterated thesis-antithesis-synthesis.

(Stage IV) In the 1900's Peirce corrected the nominalism of his pragmatism of Stage II by his strongly realistic doctrine of "would be's": Thirds are not merely summaries of fact but are real potentialities and final causes. He applied this realism to natural classes, causal laws, and dispositional probabilities. He then re-formulated his pragmatism of Stage II as a realistic and cosmically teleological pragmatism, and he planned to develop a value foundation for this more general pragmatism. He called this revised pragmatism "pragmaticism" to distinguish it from his Stage II pragmatism.

Traditional logic was normative in the sense that studying it was supposed to improve one's reasoning skills. Peirce's 1878 statement of pragmatism, "How to Make Our Ideas Clear", reflected this goal, and his 1879 "Note on the Theory of the Economy of Research" was an early use of mathematics to formulate a rational plan for research. In Stage IV Peirce argued explicitly that logic was a normative science, and he proposed to build a foundation for it of aesthetics and ethics. He also extended his earlier theories of abduction and the economy of research into a logic of discovery (which he called "hypothetic inference"), suggesting applications that today would be called "operations research".

Also in Stage IV Peirce discussed the nature of God and immortality. He stated explicitly that cosmic evolution is semiotic and inferential, i.e., that 
the processes of Tychism, Synechism, and Agapism are mental processes in God's mind.

Therefore, if you ask me what part Qualities can play in the economy of the universe, I shall reply that the universe is a vast representamen, a great symbol of God's purpose, working out its conclusions in living realities. Now every symbol must have, organically attached to it, its Indices of Reactions and its Icons of Qualities; and such part as these reactions and these qualities play in an argument that, they of course, play in the universe - that Universe being precisely an argument. In the little bit that you or I can make out this huge demonstration, our perceptual judgments are the premisses for us and these perceptual judgments have icons as their predicates, in which icons Qualities are immediately presented. But what is first for us is not first in nature....

Now as to their function in the economy of the Universe. The Universe as an argument is necessarily a great work of art, a great poem - for every fine argument is a poem and a symphony - just as every true poem is a sound argument. [5.119, boldface added]

You would never persuade me that my horse and I do not sympathize, or that the canary bird that takes such delight in joking with me does not feel with me and I with him; and this instinctive confidence of mine that it is so, is to my mind evidence that it really is so....

I hear you say: "All that is not fact; it is poetry". Nonsense! Bad poetry is false, I grant; but nothing is truer than true poetry. And let me tell the scientific men that the artists are much finer and more accurate observers than they are, except of the special minutiae that the scientific man is looking for.

I hear you say: "This smacks too much of an anthropomorphic conception". I reply that every scientific explanation of a natural phenomenon is a hypothesis that there is something in nature to which the human reason is analogous; and that it really is so all the successes of science in its applications to human convenience are witnesses. [1.314-316]

$$
* * *
$$

Each of the four stages of Peirce's thought depicts an evolutionary process, each is based on a version of the categories First-Second-Third, and each is based on a version or generalization of the logics Abduction-InductionDeduction. Moreover, each stage can be adjusted to include the earlier stages by appropriate selections from Peirce's various formulations and terminologies. Thus filtered, modified, and synthesized, the four stages constitute an evolutionary sequence in which each stage encompasses the preceeding stages. This construct is the grand unified philosophical system that Peirce wanted to construct, though, as he recognized, he was never able to expound it systematically. It is this construct that I call Peirce's evolutionary pragmatic idealism.

Although there are important similarities between Peirce's evolutionary pragmatic idealism and Hegel's absolute idealism, there are many respects 
in which Peirce's philosophy is far superior to Hegel's, and also to the absolute idealisms of Hegel's followers. Peirce created a form of cosmic and human idealism that takes account of geological and biological evolution, and he also used basic concepts from Darwin's theory of evolution, a world-shaking theory that had no influence at all on orthodox absolute idealisms. Moreover, he suggested the idea of astronomical and physical evolution.

Peirce did not derive his form of idealism from Hegel or his followers, but by a quite different route: from Kant (whom he studied intensively with his father), medieval and modern logics, philosophic semiotics (which he founded), psychology, mathematics and statistics, and the empirical sciences, including Darwinian evolution. As a young man Peirce studied chemistry and did field work with Louis Agassiz. As a scientist he did original work in mathematics, mathematical logic, and computer logic; in astronomy, geodetics, and physics; and also in empirical psychology.

Thus Peirce's evolutionary pragmatic idealism was based on modern science, mathematics, and mathematical logic, of which the other absolute idealists knew little or nothing.

As the preceding summary shows, Peirce made repeated use of his three categories of First, Second, and Third. Among other applications, he produced a classification of 66 different signs (Weiss and Burks 1945).

Peirce followed Immanuel Kant and G. W. F. Hegel in this love for triads. Kant used triads to structure his Tables of Judgments and Categories in the Critique of Pure Reason (pp. 1781, 1789). Hegel used his logical dynamic of Thesis-Antithesis-Synthesis iteratively to explain many different aspects of reality. All three philosophers found triadic categorial schemes to be useful ways of structuring their theories of reality.

Peirce's Stage III cosmic evolutionism of Tychism-Synechism-Agapism was developed from his earlier Stage I semiotic-inferential evolutionism, published in the Journal of Speculative Philosophy in 1868 69 [5.213357] under the titles 


\section{Questions Concerning Certain Faculties Claimed for Man Some Consequences of Four Incapacities \\ Grounds of Validity of the Laws of Logic: Further Conse- quences of Four Incapacities.}

Peirce begins by asking whether there are any intuitive cognitions, or cognitions determined by some thing (some reality) outside of consciousness - or whether every cognition is determined by a previous cognition, so that cognition takes place entirely in consciousness.

This question is not easy to understand, because Peirce does not state the philosophical position he is criticizing, nor is it easy to recognize the position from his criticisms of it. He is criticizing the epistemology of Kant's Critique of Pure Reason, so we will say a few words about it.

Kant held that there is an external world of objects or things-inthemselves (ding-an-sich) interacting with the human mind. The human mind has two cognitive faculties: sensibility and understanding. Objects directly presented to the senses are experienced through sensibility, which organizes them by means of its intuitive forms of space and time. The resultant intuitions are then thought in the understanding in accordance with the categories, such as the categories of substance and causality.

Thus the content of a sense experience is determined by the thingin-itself, while the spatial, temporal, and categorical organization of the experience is contributed by the mind. Compare, for example, a percept of a red table with a percept of a blue table. The difference in color between the two percepts is determined by the things-in-themselves. Likewise, the difference between a table percept and a chair percept is due to the thingin-itself. But we can know nothing of the properties of the thing-in-itself, and hence we cannot explain these differences.

Peirce abhorred such a limitation on human knowledge, and in this Journal of Speculative Philosophy series he criticized Kant's epistemology and constructed a novel alternative to it.

Peirce's approach was to argue that humans have no faculty of intuition, and hence that a cognitive-semiotic sequence has no first element. Rather, there is only a self-contained sign process:

All thought, therefore, must necessarily be in signs. ...

From the proposition that every thought is a sign, it follows that every thought must address itself to some other, must determine some other, since that is the essence of a sign. $\ldots$ every thought must be interpreted in another ... . [5.251-253]

Peirce then asked "whether there is any cognition not determined by a previous cognition", and answered: 
... to suppose that a cognition is determined solely by something absolutely external, is to suppose its determinations incapable of explanation. Now, this is a hypothesis which is warranted under no circumstances, inasmuch as the only possible justification for a hypothesis is that it explains the facts, and to say that they are explained and at the same time to suppose them inexplicable is self-contradictory....

No cognition not determined by a previous cognition, then, can be known. [5.260-262]

Thus Peirce maintained that cognition arises by a continuous process without any starting point, rather than from a starting point. To show that this is logically possible he constructs a thought experiment of an inverted triangle which is dipped in water. This conceptual triangle has no boundaries, but consists only of the points within a hypothetical triangular boundary. Topologically, the triangle is an "open area", in contrast to a triangle with boundaries, which is a closed area.

Now let any horizontal line represent a cognition, and let the length of the line serve to measure (so to speak) the liveliness of consciousness in that cognition. A point, having no length, will, on this principle, represent an object quite out of consciousness. Let one horizontal line below another represent a cognition which determines the cognition represented by the other and which has the same object as the latter. Let the finite distance between two such lines represent that they are two different cognitions. [5.263]

It is clear that in this model of the cognitive process there is no first horizontal line, and hence no first cognition.

The corresponding Kantian model of the cognitive process would be represented by a closed triangle, with a point at its lower apex that would touch the water first, and thus represent the first cognition of a cognitive process. This point would gradually grow from a point into a longer and longer horizontal line.

(Peirce was enamored of the interesting properties of mathematical continua. These play a large role in his evolutionism, for his doctrine of Synechism is based on continua.)

Thus for Peirce, knowledge is the limit point of an infinite semiotic process that has no intuitive starting point.

\section{MAN'S GLASSY ESSENCE}

Through all of the first paper of the Journal of Speculative Philosophy series and almost all of the second paper, Peirce develops his theory of cognition entirely in terms of an individual knower and his logic, though in passing he does introduce the idea of an unlimited or infinite community of philosophers:

We individually cannot reasonably hope to attain the ultimate philosophy which we pursue; we can only seek it, therefore, for the community of philosophers. [5.265] 
In focussing so long on the individual knower Peirce is following in the tradition that led to Kant.

But then, near the end of the second paper, Peirce abruptly shifts his perspective, and begins philosophizing about the infinite human cognitive community, that is, the presumed infinite history of organized human civilization. He states the essence of his position so well that I quote him at length.

... there is no thing which is in-itself in the sense of not being relative to the mind, though things which are relative to the mind doubtless are, apart from that relation. The cognitions which thus reach us by this infinite series of inductions and hypotheses (which though infinite a parte ante logice, is yet as one continuous process not without a beginning in time) are of two kinds, the true and the untrue, or cognitions whose objects are real and those whose objects are unreal. And what do we mean by the real? ... The real, then, is that which, sooner or later, information and reasoning would finally result in, and which is therefore independent of the vagaries of me and you. Thus, the very origin of the conception of reality shows that this conception essentially involves the notion of a COMMUNITY, without definite limits, and [always] capable of a definite increase in knowledge. [5.311]

Hence for Peirce, knowledge in the strict sense cannot be achieved by an individual inquirer, but only by an infinite community of inquirers, and Peirce defines both reality and truth in terms of this infinite community. This is a strong form of the realistic doctrine that the laws of nature and the properties they interconnect are real, for Peirce defines the concept of reality here in terms of infinite history. In the next paragraph [5.312], Peirce argues for the existence of real classes of events and real regularities or limiting points of inquiry that go beyond finite summaries of what has happened.

Now inquiry is a form of semiosis, and a single individual contributes to this infinite process as a member of an ongoing community. Peirce transforms this point into the thesis that the mind is a sign. His statement is long and involved, but it is typical Peirce and foreshadows much of his later thought.

Such being the nature of reality in general, in what does the reality of the mind consist? We have seen that the content of consciousness, the entire phenomenal manifestation of mind, is a sign resulting from inference. Upon our principle, therefore, that the absolutely incognizable does not exist, so that the phenomenal manifestation of a substance is the substance, we must conclude that the mind is a sign developing according to the laws of inference. What distinguishes a man from a word? There is a distinction doubtless.

[But] there is no element whatever of man's consciousness which has not something corresponding to it in the word; and the reason is obvious. It is that the word or sign which man uses is the man himself ... . the fact that every thought is a sign, taken in conjunction with the fact that life is a train of thought, proves that MAN IS A SIGN; [and since signs refer to things external to themselves] man is an external sign. That is to say, the man and 
the external sign are identical, in the same sense in which the words homo and man are identical. Thus my language is the sum total of myself; for the man is the thought.

It is hard for man to understand this, because he persists in identifying himself with his will, his power over the animal organism, with brute force. Now the organism is only an instrument of thought. But the identity of a man consists in the consistency of what he does and thinks, and consistency is the intellectual character of a thing; that is, is its expressing something.

Finally, [just] as what anything really is, is what it may finally come to be known to be in the ideal state of complete information, so that REALITY DEPENDS ON THE ULTIMATE DECISION OF THE COMMUNITY; so thought is what it is, only by virtue of its addressing a future thought which is in its value as thought identical with it, though more developed. In this way the existence of thought now depends on what is to be hereafter; so that it has only a potential existence, dependent on the future thought of the community.

The individual man, since his separate existence is manifested only by ignorance and error, so far as he is anything apart from his fellows, and from what he and they are to be, is only a negation. This is man,

“... proud man,

Most ignorant of what he's most assured,

His glassy essence".

[5.313-317, boldface and capitalization added]

Thus ends the paper!

Peirce is quoting from Shakespeare:

Could great men thunder

As jove himself does, Jove would nere be quiet,

For every pelting, petty officer

Would use his heaven for thunder,

Nothing but thunder! Merciful heaven!

Thou rather with thy sharp and sulfurous bolt

Splits the unwedgeable and gnarled oak

Than the soft myrtle; but man, proud man,

Dress'd in a little brief authority,

Most ignorant of what he's most assur'd-

His glassy essence - like an angry ape,

Plans such fantastic tricks before high heaven

As make the angels weap; who, with our spleens,

Would all themselves laugh mortal.

[Measure for Measure, act 2, scene 2, lines 111-123; bold italics added]

What, then, is man's essence, and why is it glassy? His essence is to be a reasoning sign-user in an indefinite community, and he is glassy. "Glassy" suggests a mirror:

... thought is the mirror of being, the law that the end of being and highest reality is the living impersonation of the idea that evolution generates. Whatever is real is the law of something less real. [1.487] 
"Glassy" also suggests "brittle" or "frail". A human is a fragile being, for each person is a transient sign in an infinite sign process. Finally, "glassy" suggests a crystal ball. Earlier in the scene Angelo says:

The law hath not been dead, though it hath slept.

Those many had not dar'e to do that evil,

If the first that did th' edict infringe

Had answer'd for his deed. Now 'tis awake,

Takes note of what is done, and like a prophet

Looks in a glass that shows what future evils,

Either new, or be remissness new-conceiv'd,

And so in progress to be hatch'd and born,

Are now to have no successive degrees,

But, ere they live, to end.

[Measure for Measure, act 2, scene 2, lines 90-99]

Thus in the first stage of his intellectual development Peirce rejected Kant's view that some reality external to the human mind is the causal basis of human experience, and replaced it with his own theory of an infinite semiotic process. He then defined truth and reality as follows:

And what do we mean by the real? The real, then, is that which, sooner or later, information and reasoning would finally result in, and which is therefore independent of the vagaries of me and you. Thus, the very origin of the conception of reality shows that this conception essentially involves the notion of a COMMUNITY, without definite limits, and capable of a definite increase in knowledge. [5.311]

... reality consists in the agreement that the whole community would eventually come to... this theory of reality... makes all reality something which is constituted by an event indefinitely future. [5.331]

Thus there is an opinion that the presumed infinite history of human inquiry approaches as a limit, and this is defined to be the truth.

Now human life is finite so no human or organization of humans attains truth in this limiting sense, and Peirce has not given practical definitions of truth and reality. We will return to this issue in the sections "Tychism" and "Pragmatism". 
man, and developed it in three successive stages throughout the remainder of his life. In all four stages he makes the destiny of the evolutionary process the highest reality.

His Stage I formulation was in terms of the infinite community of human sign users. In Stage II Peirce focussed on the infinite community of scientific inquirers, of which he was a self-conscious member throughout his life. The result was his famous pragmatic theory of meaning of the Popular Science Monthly series of 1877-78. "How to Make Our Ideas Clear" gives the analysis for categorical statements: the meaning of a statement consists of its practical consequences. Later papers in the series extend pragmatism to probabilistic statements. A group of inquirers gathers a finite amount of information about the relative frequency of a phenomenon and takes this observed frequency as a sign of the limiting relative frequency or probability.

In Stage III of his philosophizing, Peirce analogized from the infinite semiotic inferential evolutionism of the human community to an infinite cosmic evolutionism (Tychism-Synechism-Agapism). Although this was a very big analogical jump, Peirce made only two brief references to the fact that he was making it! In neither case did he tell the reader that he was extrapolating from human evolution to cosmic evolution! The first of the two references was in "The Law of Mind" [6.102-163]:

The tendency to regard continuity, in the sense in which I shall define it, as an idea of prime importance in philosophy may conveniently be termed synechism. The present paper is intended chiefly to show what synechism is, and what it leads to. I attempted, a good many years ago, to develop this doctrine in the Journal of Speculative Philosophy (Vol. II); but I am able now to improve upon that exposition .... .

Logical analysis applied to mental phenomena shows that there is but one law of mind, namely, that ideas tend to spread continuously and to affect certain others which stand to them in a peculiar relation of affectibility. In this spreading they lose intensity, and especially the power of affecting others, but gain generality and become welded with other ideas. [6.103-104; boldface added]

Peirce's second reference to the derivation of his Stage III cosmic evolutionism from his Stage I human evolutionism occurs late in "Man's Glassy Essence" [6.238-271]. This paper is Peirce at his frustrating best: nowhere is the phrase "man's glassy essence" explained or even used in the paper! Moreover, most of the paper is about highly technical physics and physiology, including a pioneering attempt at a molecular explanation of habit. Finally, near the end of the paper Peirce suddenly starts talking philosophy, and he ends with an intriguing theory of consciousness:

The consciousness of a general idea has a certain "unity of the ego," in it, which is identical when it passes from one mind to another. It is, therefore, quite analogous to a person; and, indeed, a person is only a particular kind of general idea. Long ago, in the Journal of 
Speculative Philosophy (Vol. II, p. 156), I pointed out that a person is nothing but a symbol involving a general idea; but my views were, then, too nominalistic to enable me to see that every general idea has the unified living feeling of a person.

All that is necessary, upon this theory, to the existence of a person is that the feelings out of which he is constructed should be in close enough connection to influence one another. Here we can draw a consequence which it may be possible to submit to experimental test. Namely, if this be the case, there should be something like personal consciousness in bodies of men who are in intimate and intensely sympathetic communion. It is true that when the generalization of feeling has been carried so far as to include all within a person, a stopping-place, in a certain sense, has been attained; and further generalization will have a less lively character. But we must not think it will cease. Esprit de corps, national sentiment, sym-pathy, are no mere metaphors. None of us can fully realize what the minds of corporations are, any more than one of my brain cells can know what the whole brain is thinking. But the law of mind clearly points to the existence of such personalities .... [6.270-271]

We will return to this quotation at the end of the paper.

\section{TYCHISM}

Peirce, like most idealists, took the human mind as a model of the universe - the knower as the model of the known. He was also an empirical scientist, and in that role he took the human mind to be a representative sample of the history of the universe. He emphasized the logical and semiotic activities of humans, and generalized from them to the infinite past and to the infinite future. The theme "the human sign user is a symbol of the universe" runs through all four stages of Peirce's philosophy.

At the time, physicists generally held that the basic laws of nature are all categorically universal; that is, they are all of the form

For any situation $s$ : if condition $C$ obtains at $s$, then result $R$ will obtain at $s$.

The contrast is with statistical or probabilistic laws. The equations governing the movements of the planets around the sun are a good example of categorical universality, for the present state of the solar system mathematically entails any future state. Peirce was exceptional in rejecting the categorical universality of the basic laws of physics, and in holding that all laws of nature are statistical or probabilistic. According to modern quantum mechanics they are.

Peirce gave two arguments for his thesis that all laws of nature are probabilistic or statistical.

The first argument arose from his research at the Coast and Geodetic Survey. He made precise measurements of the strength of gravity at various 
places in the United States and Europe. Scientific measurements always involve experimental error or uncertainty, which is usually attributed to the experimenter and the equipment. But Peirce argued that not all of the uncertainty is measurement error, that some of it is intrinsic to nature. $\mathrm{He}$ concluded that every physical law is intrinsically imprecise, involving at least a small amount of statistical variation. In other words, every physical law is at least slightly statistical.

It should be noticed that this is a novel argument against determinism. The usual indeterminist accepts that there are logically universal scientific laws, and then argues that this body of laws does not completely rule nature.

Peirce's second argument against the doctrine that all laws are categorically universal is also novel, but more complicated. It derives from his rejection of the claim that some statements can be known with certainty. Consider the view that each of us can know some aspect of our experiences directly but other agents can know these aspects only indirectly. Examples are: "it appears to me that there is a round table over there" and "I feel a pain in my side". Some philosophers hold that with sufficient care such appearance statements can be known with certainty, and that this certainty is a starting point for empirical knowledge of the things outside of us (the external world).

Such appearance statements are said to be known directly, by the faculty of intuition. But Peirce's goal in his 1868-69 Journal of Speculative Philosophy series was to show that humans have no faculty of intuition. He then developed the alternative view that all empirical knowledge is gained by a semiotic process of inference and hence by the use of signs and symbols.

Every unidealistic philosophy supposes some absolutely inexplicable, unanalyzable ultimate ... . Now that anything is thus inexplicable can only be known by reasoning from signs. But the only justification of an inference from signs is that the conclusion explains the fact. To suppose the fact absolutely inexplicable, is not to explain it, and hence this supposition is never allowable. [5.265]

Finally, no present actual thought (which is a mere feeling) has any meaning, any intellectual value; for this lies not in what is actually thought, but in what this thought may be connected with in representation by subsequent thoughts; so that the meaning of a thought is altogether something virtual. [5.289]

Peirce believed that evolution proceeds forever and approaches a limit, and hence that truths exist.

[In my opinion there is a fundamental weakness in Peirce's way of defining empirical truth. His definition covers universal statements but not particular statements, since the latter do not refer to infinite sequences. 
But universal truths are derived from singular truths by induction. Hence Peirce's doctrine that no present thought has meaning has a fatal consequence: for all practical purposes, meanings are lost in an infinite regress. (See Burks 1977, secs. 3.4.2 \& 5.6; 1981, p. 291).]

Now if no empirical statement can be known with certainty, there are no basic facts on which explanations can be grounded. From this Peirce concludes that everything needs to be explained: one of his mottos was "Do not block the road of inquiry"

Do not block the way of inquiry.

... to set up a philosophy which barricades the road of further advance toward the truth is the one unpardonable offence in reasoning .... . (1.135-6, c. 1899)

But every fact of a general or orderly nature calls for an explanation; and logic forbids us to assume in regard to any given fact of that sort that it is of its own nature absolutely inexplicable. This is what Kant (after the Scholastics) calls a regulative principle, that is to say, an intellectual hope.

...

Among other regular facts that have to be explained is law or regularity itself.

...

Moreover, conformity with law is a fact requiring to be explained; and since law in general cannot be explained by any law in particular, the explanation must consist in showing how law is developed out of pure chance, irregularity, and indeterminacy. (1.405-7, c. 1890)

Thus Peirce's explanation of the existence of regularities and laws is that these have been created ex nihilo (from the primitive chaos of feelings) by the very gradual operation of the cosmic law of evolution (TychismSynechism-Agapism).

Lamarck's theory that small living things arose spontaneously from nonliving things blocked the road to inquiry, for it gave a one-shot explanation of the origin of life rather than a gradual explanation. Since then a gradual explanation of the origin of life from chemicals has been developed.

Peirce introduces his doctrine that all laws are probabilistic at 6.33 of the first essay of the 1891-93 Monist series, "The Architecture of Theories". He defends the doctrine at length in the second essay ("The Doctrine of Necessity Examined"), but does not name it until the beginning of the third essay (at 6.102 of "The Law of Mind"). He calls the doctrine "tychism", from a Greek word meaning chance.

Peirce's doctrine of Tychism leads naturally to Synechism, his doctrine that laws evolve continuously from randomness to regularity.

The infallibilist naturally thinks that everything always was substantially as it is now. Laws at any rate being absolute could not grow. They either always were, or they sprang instantaneously into being by a sudden fiat like the drill of a company of soldiers. This makes the laws of nature absolutely blind and inexplicable. Their why and wherefore can't be asked. This absolutely blocks the road of inquiry. ... If all things are continuous, the universe 
must be existence. There is no difficulty in conceiving existence as a matter of degree. The reality of things consists in their persistent forcing themselves upon our recognition. If a thing has no such persistence, it is a mere dream. Reality, then, is persistence, is regularity. In the original chaos, where there was no regularity, there was no existence. It was all a confused dream. This we may suppose was in the infinitely distant past. But as things are getting more regular, more persistent, they are getting less dreamy and more real. [1.175]

\section{THE COSMIC LAW OF MIND}

Thus for Peirce, both the existence of laws of nature and their statistical character need to be explained.

... a uniformity, or law, is par excellence, the thing that requires an explanation. (6.612)

Now to suppose a thing inexplicable is not only to fail to explain it, and so to make an unjustifiable hypothesis, but much worse, it is to set up a barrier across the road of science, and to forbid any attempt to understand the phenomenon. (6.171)

In the first article ("The Architecture of Theories") of his 1891-93 series in The Monist Peirce gives his answer:

Now the only possible way of accounting for the laws of nature and for uniformity in general is to suppose them results of evolution. This supposes them not to be absolute, not to be obeyed precisely. It makes an element of indeterminacy, spontaneity, or absolute chance in nature. (6.13)

And since he took the human mind to be a model of the universe, he looked to his three psychological categories to see how this process of evolution works:

Passing to psychology, we find [that] the elementary phenomena of mind fall into three categories. First, we have Feelings, comprising all that is immediately present, such as pain, blue, cheerfulness, the feeling that arises when we contemplate a consistent theory, etc. A feeling is a state of mind having its own living quality, independent of any other state of mind.

...

Besides Feelings, we have Sensations of reaction; as when a person blindfold suddenly runs against a post, when we make a muscular effort, or when any feeling gives way to a new feeling.... The sense of reaction is thus a sense of connection or comparison between feelings .... .

Very different both from feelings and from reaction-sensations or disturbances of feeling are general conceptions. When we think, we are conscious that a connection between feelings is determined by a general rule, we are aware of being governed by a habit....

The one primary and fundamental law of mental action consists in a tendency to generalization. Feeling tends to spread; connections between feelings awaken feelings; neighboring feelings become assimilated; ideas are apt to reproduce themselves. These are so many formulations of the one law of the growth of mind. [6.18-21] 
Peirce then contrasts mental with physical laws.

The law of habit exhibits a striking contrast to all physical laws in the character of its commands. A physical law is absolute. What it requires is an exact relation. ... On the other hand, no exact conformity is required by the mental law. Nay, exact conformity would be in downright conflict with the law; since it would instantly crystallize thought and prevent all further formation of habit. The law of mind only makes a given feeling more likely to arise. [6.23]

(This quotation illustrates Peirce's preference for making striking statements without adding needed qualifications. As we saw in the last section, he held that every physical law is at least slightly statistical, which contradicts the physicist's belief that a law specifies "an exact relation". Hence he should have said that physicists formulate physical laws as absolute, though these laws are in fact only almost absolute.)

Peirce calls his cosmic law of mind by various names: "synechism", "the law of habit", "the mental law", "the general law of mental action", and "the law of mind". He introduces the law as follows:

The next step in the study of cosmology [after tychism] must be to examine the general law of mental action. ... The tendency to regard continuity, in the sense in which I shall define it, as an idea of prime importance in philosophy may conveniently be termed synechism. The present paper is intended chiefly to show what synechism is, and what it leads to. I attempted, a good many years ago, to develop this doctrine in the Journal of Speculative Philosophy (Vol. II) [5.213-357]; but I am able now to improve upon that exposition, in which I was a little blinded by nominalistic prepossessions. I refer to it, because students may possibly find that some points not sufficiently explained in the present paper are cleared up in those earlier ones.

Logical analysis applied to mental phenomena shows that there is but one law of mind, namely, that ideas tend to spread continuously and to affect certain others which stand to them in a peculiar relation of affectibility. In this spreading they lose intensity, and especially the power of affecting others, but gain generality and become welded with other ideas. [6.103-104]

Peirce also spoke of "the tendency to generalize", "the spreading of ideas", and "habit taking".

[The reader may notice that parts of the preceding quotation were quoted already, near the end of the section "Man's Glassy Essence". But they play a different role here than in the earlier context.]

Peirce's law of mind is clearly a generalization from the psychologist's law of association by similarity and contiguity, and thus a generalization from a law governing the human mind to the basic law governing the cosmos, or absolute mind. In other words, Peirce took human learning as a model for cosmic learning. The last paragraph of "The Law of Mind" is:

I have thus developed as well as I could in a little space the synechistic philosophy, as applied to mind. I think that I have succeeded in making it clear that this doctrine gives room for 
explanations of many facts which without it are absolutely and hopelessly inexplicable; and further that it carries along with it the following doctrines: first, a logical realism of the most pronounced type; second, objective idealism; third, tychism, with its consequent thorough-going evolutionism. We also notice that the doctrine presents no hindrances to spiritual influences, such as some philosophies are felt to do. $(6.163 ; \mathrm{cf} .6 .271)$

I will make two comments on this quotation.

(First comment) William James also thought that spiritual phenomena might give empirical evidence for some form of Diety. James was Peirce's most loyal friend, helping Peirce when he was in need more than anyone else. Soon after James died, in 1910, Peirce wrote perceptively about James and Peirce's own relation to him.

His comprehension of men to the very core was most wonderful. Who, for example, could be of a nature so different from his as I? He so concrete, so living; I a mere table of contents, so abstract, a very snarl of twine. Yet in all my life I found scarce any soul that seemed to comprehend, naturally, [not] my concepts, but the mainspring of my life better than he did. He was even greater [in the] practice than in the theory of psychology. [6.184]

(Second comment) In the quotation 6.163 (1892) Peirce defined synechism to be a cosmological law. But in 1902 Peirce defined synechism differently, as a regulative principle of logic:

[Synechism is] that tendency of philosophical thought which insists upon the idea of continuity as of prime importance in philosophy and, in particular, upon the necessity of hypotheses involving true continuity.

Now, to suppose a thing inexplicable is not only to fail to explain it, and so to make an unjustifiable hypothesis, but, much worse, it is to set up a barrier across the road of science, and to forbid all attempt to understand the phenomenon.

Synechism is not an ultimate and absolute metaphysical doctrine; it is a regulative principle of logic, prescribing what sort of hypothesis is fit to be entertained and examined. [6.169173]

We saw in the section on Tychism how Peirce used this regulative principle of synechism to argue for the thesis that all laws of nature are statistical: to assume unchanging deterministic laws is "to block the road of scientific inquiry". Instead, Peirce explained the existence of laws in terms of their very gradual or synechistic evolution from chaos.

Peirce thought logic should be treated as a normative science of reasoning, and so for him the three logical modes of abduction (First), induction (Second), and deduction (Third) constitute the deliberate and controlled operations of the human mind. 
By hypothetic inference [abduction] a number of reactions called for by one occasion get united in a general idea which is called out by the same occasion. [6.146]

By induction, a habit becomes established. [6.145]

In deduction the mind is under the dominion of a habit or association. ... That is the way the hind legs of a frog, separated from the rest of the body, reason, when you pinch them. $(6.144,1892$, with italics added)

This last comment illustrates the depth of Peirce's understanding of the role of logic in nature. He elucidates his meaning in his 1883 Studies in Logic volume:

... a syllogism in Barbara virtually takes place when we irritate the foot of a decapitated frog. The connection between the afferent and efferent nerve ... constitutes a nervous habit, a rule of action, which is the physiological analogue of the major premiss. The disturbance of the ganglionic equilibrium, owing to the irritation, is the physiological form of that which, psychologically considered, is a sensation; and, logically considered, is the occurrence of a case. The explosion through the efferent nerve is the physiological form of that which psychologically is a volition, and logically the inference of a result. [2.711, 1883; cf. 3.154-161, 1880]

It is well known today that a neuron is a mixed analog-digital logical switch and computing device.

Thus Peirce recognized that neurons are logical elements, and he was the first to do so. At about the same time he recognized that electromagnetic relays could be used to do logic. Furthermore, he saw that relays could be used to build an electrical version of Charles Babbage's analytical engine. In both cases, he was more than 50 years ahead of his time. (See Burks and Burks 1988a and 1988b.)

Peirce believed that a machine could not discover interesting theorems or do original work (Peirce 1887). In contrast, I have argued that a finite automaton can perform all human functions (Burks 1972-73, 1986, 1990).

\section{TYCHISM-SYNECHISM-AGAPISM}

Although Peirce was a founder of semiotics and understood in principle the value of well-defined terms in technical writing, he was too rhetorical and impractical to follow that principle in his own philosophical writing. For example, in "The Law of Mind" he uses four different names for the subject of the paper: "the law of mind" $[6.104,6.127,6.150]$, "the general law of mental actions" [6.103], "the law of continuous spreading", and "synechism" [6.103, 6.163]. More important, he seems to leave the reader without any name for his grand law of cosmic evolution. That is why 
I introduced the technical term "Tychism-Synechism-Agapism" for this law (in the first section of this paper).

The doctrines of Tychism, Synechism, and Agapism constitute the core of Peirce's evolutionary pragmatic idealism. That philosophy also includes Peirce's concept of God, his teleological pragmaticism with its associated doctrines of final causality and concrete reasonableness, his modal realism of "would-be's" or real potentialities, and his conception of logic as a normative science.

Tychism-Synechism-Agapism is the basic principle governing the creation, evolution, and destiny of the cosmos. Peirce is a panpsychist, making feelings (psychological firsts) the elementary building blocks of the universe. The universe starts as a chaos of these feelings, not even organized in space and time. In our time the evolutionary process has reached the mixed ordered and chaotic state we know. In the future the cosmos will move on indefinitely toward a perfectly ordered and rational system.

$\ldots$ in the beginning - infinitely remote - there was a chaos of unpersonalized feeling, which being without connection or regularity would properly be without existence. This feeling, sporting here and there in pure arbitrariness, would have started the germ of a generalizing tendency. Its other sportings would be evanescent, but this would have a growing virtue. Thus, the tendency to habit would be started; and from this, with the other principles of evolution, all the regularities of the universe would be evolved. At any time, however, an element of pure chance survives and will remain until the world becomes an absolutely perfect, rational, and symmetrical system, in which mind is at last crystallized in the infinitely distant future. [6.33-1891]

This passage gives Peirce's metaphysical extrapolation, both backward and forward, of the 19th century doctrine of progress. Cosmic evolution began as an unorganized set of feelings, gradually evolved things and laws organized in space and time, then living things, and finally we humans and our social organizations. This evolutionary process will continue on, moving towards cosmic goals. By the very nature of a limit, the goals of the process will never be reached, so that at any particular moment there will be some randomness, some imperfection, and some room for improvement.

In characterizing the destiny of the universe in this way, Peirce had in mind the Hindu and Buddhist ideas of Nirvana. At the beginning of "The Law of Mind" he summarizes what he has shown in the two preceeding papers of The Monist series:

... tychism must give birth to an evolutionary cosmology in which all the regularities of nature and of mind are regarded as products of growth, and to a Schelling-fashioned idealism which holds matter to be mere specialized and partially deadened mind. I may mention, for the benefit of those who are curious in studying mental biographies, that I was born and reared in the neighborhood of Concord - I mean in Cambridge - at the time when Emerson, Hedge, and their friends were disseminating the ideas that they had caught 
from Schelling, and Schelling from Plotinus, from Boehm, or from God knows what minds stricken with the monstrous mysticism of the East. [6.102]

Christine Ladd-Franklin was a noted psychologist and logician who had studied with Peirce at Johns Hopkins University. In an 1891 letter to her Peirce said:

... my cosmology ... is that the evolution of the world is hyperbolic, that is, proceeds from one state of things in the infinite past, to a different state of things in the infinite future. The state of things in the infinite past is chaos, toho bohu, the nothingness of which consists in the total absence of regularity. The state of things in the infinite future is death, the nothingness of which consists in the complete triumph of law and the absence of all spontaneity. Between these, we have on our side a state of things in which there is some absolute spontaneity counter to all law, and some degree of conformity of law, which is constantly on the increase owing to the growth of habit. The tendency to form habits or tendency to generalize, is something which grows by its own action, by the habit of taking habits itself growing. Its first germs arose from pure chance. There were slight tendencies to obey rules that had been followed, and these tendencies were rules which were more and more obeyed by their own action. There were also slight tendencies to do otherwise than previously, and these destroyed themselves. To be sure, they would sometimes be strengthened by the opposite tendency, but the stronger they became the more they would tend to destroy themselves. As to the part of time on the further side of eternity which leads back from the infinite future to the infinite past, it evidently proceeds by contraries.

I believe the law of habit to be purely psychical. But then I suppose matter is merely mind deadened by the development of habit. While every physical process can be reversed without violation of the law of mechanics, the law of habit forbids such reversal. Accordingly, time may have been evolved by the action of habit. At first sight, it seems absurd or mysterious to speak of time being evolved, for evolution presupposes time. But after all, this is no serious objection, and nothing can be simpler. Time consists in a regularity in the relations of interacting feelings. The first chaos consisted of an infinite multitude of feelings. As there was no continuity about them, it was, as it were, a powder of feelings. It was worse than that, for of particles of powder some are nearer together, others farther apart, while these feelings had no relations, for relations are general. [8.317-318]

As Peirce recognizes, the idea that time itself evolved seems absurd. It certainly violates common sense, but so does the current big-bang theory of the origin of the universe. This theory states that the universe started as a point atom ("cosmic egg") which exploded at the beginning of time, and since then space has constantly expanded, like the surface of an expanding 3-dimensional sphere. When I was a graduate student many philosophers rejected Albert Einstein's special theory of relatively because of the relatively of simultaneity: it seemed obvious to them that there is only one time-frame. And yet the special theory of relatively implies the interconvertibility of matter and energy, of which the atom bomb was a practical consequence!

Peirce had a relational theory of the nature of space and time. According to this theory, space and time are relations connecting objects and events, 
and so space and time cannot exist until objects and events exist. As the ultimate atoms of the universe, panpsychic feelings (Firsts) are too simple to be related by space and time. Objects and events are relational complexes of Firsts, and are organized by the relations of space and time. This is the sense in which space and time have evolved under the cosmological principle of Tychism-Synechism-Agapism.

$$
* * *
$$

Thus for Peirce evolution is a hierarchical process with three aspects:

First: TYCHISM (from the Greek word meaning chance), the doctrine that probabilistic laws are basic, and deterministic laws are limiting cases of them

Second: SYNECHISM (from the Greek word meaning continuity), the doctrine that reality is in a strictly continuous process of evolutionary development, moving from a state of complete randomness toward perfect regularity

Third: AGAPISM (from the Greek word meaning love), the doctrine that cosmic evolution is goal-directed, governed by final causes. For "agapism" Peirce also used "evolutionary love" and "final cause".

According to Tychism the primitive chaos consisted of elementary feelings (psychological Firsts). Slight tendencies to obey rules developed by chance, and some of these probabilistic connections developed into habits and laws of nature. The most primitive atoms of the universe are feelings (psychological Firsts), and the universe began as a chaos of feelings.

Synechism is the doctrine that natural classes, laws, and systems of the universe evolve continuously in the strict mathematical sense. The spreading of feelings and the growth of generalizations are continuous. Modern genetics tells us that this is not so, that evolution actually proceeds in very small discrete steps. But with this mathematical adjustment, Peirce's characterization of evolution as a growing, developmental, learning process is essentially correct (Burks 1991).

Agapism is the doctrine that the synechistic evolution of tychistic laws is guided by Aristotelian final causes. We give several quotes from Peirce on this point.

To say that the future does not influence the present is untenable doctrine. It is as much to say that there are no final causes, or ends. The organic world is full of refutations of that position. Such action constitutes evolution ... [2.86]

... physical evolution works toward ends in the same way that mental action works toward ends, and thus ... final causation is alone primary. [6.101] 
... ideas are not all mere creations of this or that mind, but on the contrary have the power of finding or creating their vehicles, and having found them, of conferring on them the ability to transform the face of the earth. [1.217]

[In a letter to William James Peirce said:]

I say to people,--imaginary interlocutors, for I have nobody to talk to, - you think that the proposition that truth and justice are the greatest powers in this world, is metaphorical. Well, I, for my part, hold it to be true. No doubt Truth has to have defenders to uphold it. But truth creates its defenders and gives them strength. The mode in which the idea of truth influences the world is essentially the same as that in which my desire to have the fire poked causes me to get up and poke it. There is efficient causation and there is final, or ideal, causation. If either of them is to be set down as a metaphor, it is rather the former. [8.272]

But the being governed by a purpose or other final cause is the very essence of the psychical phenomenon, in general. [1.269]

The mind works by final causation, and final causation is logical causation. Note, for example, the intimate bearing of logic upon grammatical syntax. Moreover, everything in the psychical sciences is inferential. [1.250, boldface added]

$$
* * *
$$

Peirce suggests an analogy between his three aspects of cosmic evolution, Tychism, Synechism, Agapism

and his three kinds of human logic,

abduction, induction, and deduction [cf. 6.144-145].

Tychism is a cosmic generalization of abduction, and synechism of induction, but the analogy from deduction to agapism is only suggestive.

The random start of evolution is a cosmic abduction, and both human and cosmic tychism are random searches. Peirce was an exponent of the frequency theory of inductive probability, and the continuous growth of Synechism is a continuous generalization of the gradual convergence of observed relative frequencies toward the limit of a statistical sequence.

Agapism refers to the role of final causes in evolution, and in the last quotation given above Peirce says that "final causation is logical causation". He also says

... the universe is a vast representamen, a great symbol of God's purpose, working out its conclusions in living realities. Now every symbol must have, organically attached to it, its Indices of Reactions and its Icons of Qualities; and such part as these reactions and these qualities play in an argument, they of course, play in the universe - that Universe being 
precisely an argument.

$\cdots$

The Universe as an argument is necessarily a great work of art, a great poem - for every fine argument is a poem and a symphony - just as every true poem is a sound argument. [5.119]

The very being of the General, of Reason consists in its governing individual events. (1.615)

Peirce called his own account of evolution "objective logic because that conveys the correct idea that it is like Hegel's logic" (1.444), and he thought that Hegel's logic was closer to deductive logic than to abduction and induction [5.436 and 6.218].

Agapism is the teleological force that steers the evolving universe toward an absolutely perfect, rational, and symmetrical form. This force is somewhat analogous to the Platonic force of mathematical and value forms.

... the existing universe, with all its arbitrary secondness, is an offshoot from, or an arbitrary determination of, a world of ideas, a Platonic world; not that our superior logic has enabled us to reach up to a world of forms to which the real universe, with its feebler logic, was inadequate.

If this be correct, we cannot suppose the process of derivation, a process which extends from before time and from before logic, we cannot suppose that it began elsewhere than in the utter vagueness of completely undetermined and dimensionless potentiality.

The evolutionary process is, therefore, not a mere evolution of the existing universe, but rather a process by which the very Platonic forms themselves have become or are becoming developed. [6.192-194]

Peirce is saying that cosmic Firsts are occurrences of specific universals (i.e., specific properties), and that as cosmic evolution proceeded, final causality organized these specific universals into generic universals (natural classes). These generic universals then functioned as properties in natural laws. For example, different specific shades of red may come to be grouped together as the identifying color of a species, and the quantity of mass becomes a factor in the force of gravity. (Cf. Burks 1988b; 1990, pp. 449-455)

Thus in his formulation of the doctrine of final causation, Peirce is clearly returning to Plato's doctrine that the IDEAS - especially THE TRUE, THE GOOD, and THE BEAUTIFUL - have cosmic force, and also to Aristotle's related doctrine of Final Causes. 


\section{PEIRCE'S PANPSYCHIC FIRSTS}

Peirce had two distinct philosophical theories of evolution. The first was his semiotic-cognitive theory of the Journal of Speculative Philosophy (Stage I), which he extended in Stage II to include his pragmatism. His second theory was the Stage III cosmic evolutionism of Tychism-SynechismAgapism, expounded in The Monist. This theory was augmented somewhat by his Stage IV pragmaticism.

As we saw in the last section, Tychism is based on Peirce's concept of an "unpersonalized feeling" or "cosmic First", and that is one of the most difficult concepts in his philosophy. Surprisingly, an unpersonalized feeling or cosmic First is similar to what Immanuel Kant called a "sensation" or "the content of a sense experience" (see the second section of this paper). However, Kant's sensations are limited to the human mind, whereas Peirce's unpersonalized feelings are also the most fundamental atoms or building blocks of the universe. This comparison is important for understanding Peirce's philosophical development, and so I will describe how Peirce expanded his semiotic-cosmic evolutionism of State I into his cosmic evolutionism of Stage III.

In Stage I Peirce rejected Kant's thesis that there is a thing-in-itself (ding-an-sich) external to our minds that accounts for the basic content of a perception of the external world. Peirce did this because on Kant's theory the relation of a sensation to the thing-in-itself is unknowable. However, Peirce's rejection of the thing-in-itself left the cosmos without any constituent independent of human minds! That result in turn implied that both the environment and pre-human history are human constructions! And indeed, Peirce's semiotic-cognitive theory of evolution of Stages I and II is limited to human and social evolution. The theory says nothing about what happened before humans evolved!

In Stage III Peirce expanded his evolutionary perspective dramatically by developing the cosmic evolutionism of Tychism-Synechism-Agapism. This included the doctrine that unpersonalized feelings are the fundamental atoms of the universe.

... in the beginning - infinitely remote - there was a chaos of unpersonalized feeling, which being without connection or regularity would properly be without existence. This feeling, sporting here and there in pure arbitrariness, would have started the germ of a generalizing tendency. [6.33, italics added]

These "unpersonalized feelings" are also what Peirce called psychological Firsts. He characterized them as follows:

... feeling, the consciousness that can be included within an instant of time, passive consciousness of quality, without recognition or analysis. [1,377] 
... Feelings, comprising all that is immediately present, such as pain, blue, cheerfulness, the feeling that arises when we contemplate a consistent theory, etc. A feeling is a state of mind having its own living quality, independent of any other state of mind. A feeling is necessarily perfectly simple, for if it had parts these would also be in the mind, whenever the whole was present, and thus the whole would not monopolize the mind. .. [He added a footnote:] A feeling may certainly be compound, but only in virtue of a perception which is not that feeling nor any feeling at all. [6.18]

Peirce is talking here about external feelings such as colors, shapes, and sounds, as well as internal feelings.

Any flash of experience with some specific quality (perhaps vague) is an example of a psychological first, whatever the source of the experience. Suppose, for example, that you glance momentarily and seem to see a brownish spread without defined boundaries. This is a psychological First, whether it was caused by an actual table top, occurred in a dream, or resulted from a physician tickling your brain.

Peirce said explicitly that these psychological Firsts are the atomic building blocks of the cosmos:

We can hardly but suppose that those sense-qualities that we now experience, colors, odors, sounds, feelings of every description, loves, griefs, surprise, are but the relics of an ancient ruined continuum of qualities, like a few columns standing here and there in testimony that here some old-world forum with its basilica and temples had once made a magnificent ensemble. [6.197, bold-face added]

\section{Remember that for Peirce}

... time consists in a regularity in the relations of interacting feelings. The first chaos consisted in an infinite multitude of unrelated feelings. ... these feelings had no relations, for relations are general. [8.318]

The concept of a psychological First is derived from human psychology, but the role of psychological Firsts in the tychistic origin of the universe is very different from their role in the human mind, so when talking about them in their cosmic role I call them "cosmic Firsts". Thus human psychological Firsts are both cosmic Firsts and our source of the concept of a cosmic First. And since cosmic Firsts are the fundamental atoms of the universe, we humans directly experience instances of cosmic atoms!

[This is another example of how the relational structure of Peirce's philosophy ambiguates his use of terms. The word "feelings" plays two very different roles in his philosophy, for it may refer to the basic atoms of the universe or to the atoms of the human mind.]

Peirce called his philosophy objective idealism, and that name distinguishes it from Berkeley's subjective idealism. Objective idealism is a form 
of panpsychim, the view that all objects of the universe are constituted of basic feelings and their interrelations.

Peirce's identity of psychological and cosmic Firsts is the essence of his panpsychism, and so to connect Peirce's philosophical ideology to the mainstream of philosophy I will call both psychological Firsts and cosmic Firsts panpsychic Firsts. Panpsychic Firsts are, of course, very different from, and much more basic than, such other Peircean Firsts as iconic signs and abductive arguments.

Section 2 of this paper was entitled "Humans Have no Faculty of Intuition" because the questions Peirce asked in his 1868-69 Journal of Speculative Philosophy series were about this presumed Kantian faculty. Kant said that

Objects are given to us by means of sensibility, and it alone yields us intuitions; they are thought through the understanding, and from the understanding arise concepts. [Kant 1933, p. 65]

To see how intuitions and concepts enter into cognition, we will analyze an example.

Suppose a person perceives a brown, rectangular table. Kant would analyze this percept into four factors:

(1) The thing-in-itself (ding-an-sich) causes

(2) the sensation of a table in the observer's mind.

(3) The perceived shape of the table results from the interaction of the sensation and the mind's innate form of spatial intuition.

(4) The concept of the table as a thing results from the interaction of the spatially organized sensation and the mind's innate category of substance.

We can now compare Peirce's analysis of perception with Kant's, factor by factor.

(1) Peirce had nothing like the thing-in-itself. Indeed, his main objective in Stage I of his thought was to give an account of knowledge without using the idea of something beyond experience that causes our intuitive experiences.

(3) Peirce held space to be a complex relational structure and hence a Third.

(4) A substance is an organization of properties, and every organization is a Third. 
This leaves factor (2), the bare sensation of the table in the observor's mind, not including its spatial boundaries and without being conceived as a thing. But this unstructured sensation is very similar to a Peircean psychological First, and thus to an unpersonalized feeling.

Despite this similarity with respect to factor (2) of perception, Peirce's theory of the other three factors is radically different from Kant's. Consider, for example, the fact that human percepts vary widely from one experience to another. What accounts for this variation? Kant's answer would be that the ding-an-sich accounts for it. But the ding-an-sich is not observable, and so on Kant's philosophy there can be no explanation of the differences among experiences. More generally, Kant's theory of perception cannot account for the observed variety in the universe! And as we saw in the section "Tychism", Peirce rejected all such theories on the ground that they "block the way of inquiry".

Peirce's panpsychism does explain the variation among human perceptions. The perceiver and the perceived environment belong to the same metaphysical system and so their basic atoms and laws are the same. Consider a table, the intervening environment, and the percipient's body and mind. These are all constructed of panpsychic feelings, and the laws connecting them are reducible to laws governing panpsychic feelings. For Peirce, then, perception involves interactions of compounds of panpsychic Firsts in accordance with the natural laws governing these interactions. In contrast, Kant's theory of perception involves two metaphysically different kinds of entities, the ding-an-sich and the human mind, and the laws governing their interactions are unknowable to humans.

\section{$* * *$}

Peirce's evolutionary pragmatic idealism is probabilistically constructive, for it derives the nature of the universe from an initial chaos of cosmic atoms (panpsychic Firsts), using probabilities in the derivation. Thus Peirce's explanation of the variety in human perceptions goes all the way back to the start of the cosmos in an initial chaos of panpsychic Firsts.

... in the beginning - infinitely remote - there was a chaos of unpersonalized feeling, which being without connection or regularity, would properly be without existence. (6.33)

By thus admitting pure spontaneity or life as a character of the universe, acting always and everwhere though restrained within narrow bounds by law, producing infinitesimal departures from law continually, and great ones with infinite infrequency, I account for all the variety and diversity of the universe, in the only sense in which the really sui generis and new can be accounted for. 
... my hypothesis of spontaneity [Tychism] does explain irregularity, in a certain sense; that is, it explains the general fact of irregularity, though not, of course, what each lawless event is to be. At the same time, by thus loosening the bond of necessity, it gives room for the influence of another kind of causation [final causation, or Thirdness], such as seems to be operative in the mind in the formation of associations, and enables us to understand how the uniformity of nature could have been brought about. [6.59-60]

Looked at in the reverse direction, from the indefinitely far future to the indefinitely far past, Peirce's evolutionary pragmatic idealism is probabilistically reductive. In this broad sense of "reductive" it is similar to earlier materialistic and mechanistic philosophies, though these were nonprobabilistic. My own philosophy of logical mechanism, influenced by Peirce, is evolutionararily and probabilistically reductive (Burks 1986, 1990, 1995).

It is philosophically important that Peirce's constructive panpsychism has a big advantage over reductive materialisms and mechanisms in explaining the nature of consciousness. For human feelings are direct constituents of consciousness, whereas physical components are not. Furthermore, panpsychic feelings provide a mental basis for Peirce's panpsychic God.

We go back now to Stage II of Peirce's thought, his pragmatism, and from there to his stage IV modification of it, pragmaticism.

\section{PRAGMATISM}

I outlined the four successive doctrines of Peirce's intellectual evolution at the beginning of this paper:

(I) The doctrine that man is a sign in an infinite semiotic and inferential process

(II) Pragmatism

(III) Cosmic evolutionism: Tychism-Synechism-Agapism

(IV) The realism of "would-be's" and the generalization of pragmatism to pragmaticism.

Peirce's evolutionary pragmatic idealism is the synthesis of these four doctrines.

We have covered (I) and seen how Peirce generalized from it to (III). But as we saw near the end of the section "Man's Glassy Essence", doctrine (I) yields only theoretical or limiting definitions of "truth" and "reality", in terms of an infinite semiotic process. Doctrine I does not yield practical definitions of "truth" and "reality". Since Peirce's pragmatism is based on scientific method, one would expect it to fill this gap. It does so, though only partly. 
In about 1873 , Peirce began to develop pragmatism in chapter drafts of a book, "Logic". These drafts were first published in 1958 (Collected Papers of Charles Sanders Peirce 7.313-361). Peirce published the doctrine in the Popular Science Monthly (1877-78) as a series of papers, under the general title "Illustrations of the Logic of Science":

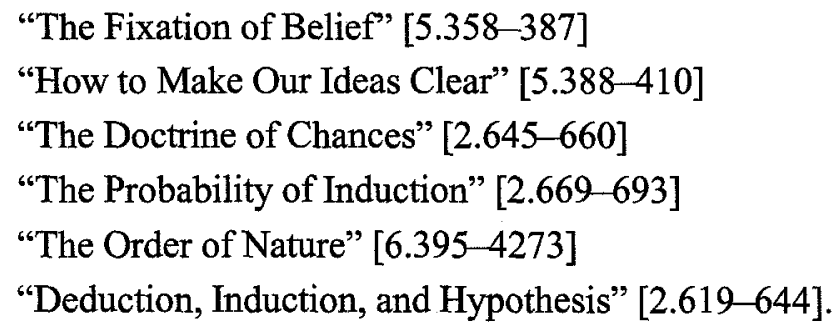

These papers constitute an advanced textbook on logic, together with Peirce's philosophical foundations of the subject.

"The Fixation of Belief" describes several methods of fixing belief and argues that the observational and experimental methods of science constitute the best of these. "How to Make Our Ideas Clear" contains Peirce's famous pragmatic maxim:

... there is no distinction of meaning so fine as to consist in anything but a possible difference of practice. [5.400]

Consider what effects, which might conceivably have practical bearings, we conceive the object of our conception to have. Then, our conception of these effects is the whole of our conception of the object. [5.402, boldface added]

... the ideas of truth and falsehood, in their full development, appertain exclusively to the scientific method of settling opinion. [5.406]

To illustrate the pragmatic method of inquiry, Peirce described several investigators, each using a different method to measure the velocity of light.

They may at first obtain different results, but, as each perfects his method and his processes, the results are found to move steadily together toward a destined centre. So with all scientific research. Different minds may set out with the most antagonistic views, but the progress of investigation carries them by a force outside of themselves to one and the same conclusion. [5.407]

Thus Peirce's pragmatism was an analysis of the nature of scientific verification and the recommendation of it as a norm. His paper on the theory 
of the economy of research [7.139-157] at about the same time was an extension of this analysis to encompass the economy of inquiry.

However, Peirce was not using "belief" in the ordinary sense in "The Fixation of Belief". For immediately after formulating pragmatism in "How to Make Our Ideas Clear" at 5.402, he considered the belief "this diamond was hard" for the case of a diamond that had been destroyed without ever having been tested for hardness. He then said

There is absolutely no difference between a hard thing and a soft thing so long as they are not brought to the test. [5.403]

A practical person would say that this is not so, for tests show that diamonds are hard, and had this particular diamond been tested it would have been found to be hard. But this is not true of soft things.

Moreover, such counterfactual beliefs are foundational to morality (Burks 1946a). Suppose a person fails to act so as to carry out a moral duty, and the consequences of his not carrying out his duty are bad. In evaluating this situation, one would say, " $\mathrm{Had}$ he acted morally the bad result would not have occurred". But applying Peirce's interpretation of the untested diamond to this example, one could equally well say, "Had he acted morally it would have made no difference"!

Peirce's difficulty here is that his 1878 concepts of truth and reality were not really applicable to single cases, or even to finite sequences of cases, but only to those infinite sequences that have limits (Burks 1977, sec. 3.4.2, 1980). This was true of his 1868 definitions [5.311], and his 1878 definitions are essentially the same:

The opinion which is fated to be ultimately agreed to by all who investigate, is what we mean by the truth, and the object represented in this opinion is the real. [5.407]

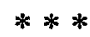

We have seen that Peirce mixed two kinds of philosophical materials in "How to Make Our Ideas Clear": a characterization of scientific method, and philosophical theses about it. The last four papers of the series contain the same interesting mixture. These papers are devoted to the three kinds of logical reasoning - deduction, induction, hypothesis (abduction) - and to philosophical issues such as the uniformity of nature and the interpretation of probability.

Thus Peirce thought his pragmatic method of inquiry rested on concepts of truth and reality that presuppose an infinite sequence of inquirers. The same is true of his analysis of inductive logic. He held the frequency theory 
of probability, which defines the probability of a property as its relative frequency in an infinite sequence of events, and he drew the obvious conclusion from this theory:

An individual inference must be either true or false, and can show no effect of probability; and, therefore in reference to a single case considered in itself, probability can have no meaning. [2.652, "The Doctrine of Chances"]

But, in fact, applications of probability and statistics are always to finite situations.

Peirce's putative solution to this problem was the same as in the case of ordinary empirical statements, to appeal to the infinite community of investigators. Thus he said in "The Doctrine of Chances":

... logicality inexorably requires that our interests not be limited. They must not stop at our own fate, but must embrace the whole community ... Logic is rooted in the social principle. [2.654]

Now this is a possible rule for conduct, but it doesn't give pragmatic meaning to any actual application of probability.

[It is worth noting that an infinite probabilistic sequence is a very simple model of Peirce's Stage I infinite inferential process. The limiting relative frequency of the sequence represents the truth, and each observed relative frequency represents the opinion of the moment. These simple probabilistic models of Stage II presage Peirce's Stage III doctrine of Tychism.]

In the fourth paper of the Popular Science Monthly series, Peirce considered the main alternative to the frequency theory of probability, what he called "the conceptualistic theory". (This theory is also called the "a priori theory of probability" - cf. Burks 1977 , secs. $5.7 \& 10.5$.) It holds that probability is "the degree of belief which ought to attach to a proposition" [2.673]. Peirce rejected this theory, saying

The relative probability of this or that arrangement of Nature is something which we should have a right to talk about if universes were as plenty as blackberries, if we could put a quantity of them in a bag, shake them well up, draw out a sample, and examine them to see what proportion of them had one arrangement and what proportion another. But, even in that case, a higher universe would contain us, in regard to whose arrangements the conception of probability could have no applicability. [2.684]

But we will see in a moment that Peirce did accept the reality of sets of possible universes when he advocated the reality of "would-be's" in Stage IV. 
Peirce's pragmatic characterization of scientific method is excellent. But his pragmatic philosophy of science is a curious mixture of extreme nominalism (denying hardness to an untestable diamond) and extreme realism (defining truth and reality in terms of an assumed infinite history of inquiry)! Since neither doctrine is practical, his Stage II philosophy of science was only partly pragmatic. Peirce resolved this conflict in Stage IV by abandoning the nominalism and adopting his realistic doctrine of "would-be's". He also made his pragmatism more reformist by his doctrine of "concrete reasonableness". These two doctrines made his stage IV pragmatism very different from his Stage II pragmatism, and so Peirce renamed his theory pragmaticism.

I will make some preliminary points as background for our discussion of pragmaticism.

The concept of final causality is derived from the purposiveness displayed by all living things, and Peirce was especially interested in what I will call human conscious-planned-rational goal-seeking. Peirce's pragmatic analysis of inquiry is a partial analysis of this concept. A person has a goal and works out a plan or strategy for achieving it. The person gathers information, makes a model of the situation, acts, observes the result, and then repeatedly cycles this procedure, often modifying the strategy or even the goal in the process. Peirce's derivation of pragmatism from inquiry yielded a theory of goal-seeking, and his work on the economy of research was a further development of this theory [7.139-161].

Consider now Peirce's theory of would-be's. I think this theory follows from his Agapism, the doctrine that final causes guide evolution towards a supreme value goal. For a purpose, whether human or cosmic, is dispositional. It can operate in many different circumstances, and when it fails to operate it may be the case that if it had operated then the goal would have been reached. Hence goal-directedness, either that of a human or the cosmos, implies the reality of "would-be's" or potentialities.

Finally, it should be noted that Peirce's Stage III Agapism and his Stage IV realism provide a metaphysical basis for his Stage I and Stage II definitions of "truth" and "reality". Both definitions presuppose that there will be an infinite history of inquiry that converges to a limit. This presupposition is supplied by the would-be aspect of cosmic final causality, which guarantees that history will continue indefinitely and approach a limit. Thus Peirce's pragmaticism helps integrate the first three stages of his thought into a single system. 
As we saw in the preceding section, Peirce interpreted a statement like

This diamond is harder than steel

nominalistically, in terms of material implication, which was the only kind of implication that had been formalized at that time. On this interpretation of "if ... then ...", the statement

If this diamond is rubbed by steel, then it will be scratched is logically equivalent to

EITHER the diamond is NOT rubbed by steel OR it is scratched. Hence if the diamond is never tested, the sentence is true, independently of the dispositional properties of diamonds and steel. Thus on Peirce's Stage II interpretation, the sentence If this diamond is rubbed by steel, it will be scratched does not entail such subjunctive conditionals as

If this diamond WERE rubbed with the point of a steel knife, then it WOULD NOT be scratched.

As we noted earlier, Peirce said in "How to Make Our Ideas Clear",

There is absolutely no difference between a hard thing and a soft thing so long as they are not brought to the test. [5.403, 1878]

On this nominalist interpretation, the sentence "This diamond is harder than steel" is only a summary of actual facts, and says nothing about contrary-to-fact possibilities.

It is worth noting that in the 1930s and 1940's many logical positivists and naturalists took Peirce's pragmatic criterion of meaning and his statements about the untested diamond statement to show that he was an early logical postivist. Some of them also held that Peirce's philosophy was schizophrenic - an untenable mixture of clear philosophy and metaphysics.

\section{$* * *$}

In 1905 and 1906, Peirce published three articles on pragmaticism in The Monist. The second of these begins with a reformulation of his 1878 definition of pragmatism, which we quoted a few pages back, but now he calls it "pragmaticism" rather than "pragmatism":

Pragmaticism was originally enounced [in 5.402, 1878] in the form of a maxim, as follows: Consider what effects that might conceivably have practical bearings you conceive the 
objects of your conception to have. Then, your conception of those effects is the whole of your conception of the object. [5.438]

Later in the paper Peirce reviews his 1878 discussion of the diamond and reverses his conclusion:

... classification is true or false, and the generals to which it refers are either reals in the one case, or figments in the other. ... the question is, not what did happen, but . . . whether that diamond would resist an attempt to scratch it... [5.4533]

Thus in Stage IV of his thought Peirce wanted his pragmaticism to encompass and promote the rational fulfillment of purposes. Since purposes and final causes are dispositional, he shifted from his nominalist summary-of-fact interpretation of conditional statements to a realist and dispositional interpretation. He now said that causal statements express causal potentialities, or "would-be's":

... the will be's, the actually is's, and the have been's are not the sum of the reals. They only cover actuality. There are besides would be's and can be's that are real ... .

It can certainly be proved very clearly that the Universe does contain both would be's and can be's. [8.216-217, c. 1910]

My modal logic of causal statements was the first formal logic of causal conditionals, or what Peirce called "would be's" (Burks 1951a; Burks 1977 , Chapters $6 \& 7$ ). I constructed this system to elucidate the logic of such statements, and to justify their use in moral contexts (Burks 1946a). Causal implication is logically stronger than material implication, the kind of implication Peirce assumed in "How to Make Our Ideas Clear". A modal logic is a logic of possible universes, and my logic of causal statements is a logic of causally possible universes. Thus Peirce's doctrine of "would be's" implies the reality of possible universes he denied when he said that universes are not "as plenty as blackberries" [2.684].

Correspondingly, Peirce moved in Stage IV from his Stage II nominalist theory of frequency probability to a realist and dispositional theory of probability:

... the statement that the probability, that if a die be thrown from a dice box it will turn up a number divisible by three, is one-third ... means that the die has a certain "would be"; and to say that a die has a "would-be" is to say that it has a property, quite analogous to any habit that a man might have. Only the "would-be" of the die is presumably as much simpler and more definite than the man's habit as the die's homogeneous composition and cubical shape is simpler than the nature of the man's nervous system and soul... [2.664]

My own theories of probability, induction, and causality were influenced by Peirce, both positively and in reaction to his theories. See my Chance, Cause, Reason (1977). Peirce's frequency theory of probability and his later dispositional-frequency theory are analyzed in Chapters 3 and 8 . My 
theory of inductive probability is developed in Chapters 4 and 5 , and is based on my calculus of choice. This is a graphical logic relevant to human conscious-planned rational goal-seeking. Choice trees are used to represent alternative strategies or plans of action, and a strategy is chosen by marking a choice tree in accordance with a set of rules that entail the applicability of probability theory. Interestingly, Peirce devoted his third Monist article on pragmaticism [4.530-572] to a graphical logic for deductive reasoning and the concept of logical necessity (Roberts 1973).

$* * *$

We are now ready to discuss Peirce's concept of concrete reasonableness. Throughout his whole career Peirce developed the logic of reasoning and advocated its use. His pragmatISM was a logic for achieving the goal of human knowledge. His pragmatICISM held that concrete reasonableness is the goal of cosmic evolution, and Peirce advocated that human reason be used to further this goal.

[According to pragmaticism] the only ultimate good is ... to further the development of concrete reasonableness, so that the meaning of the concept does not lie in any individual reactions at all, but in the manner in which those reactions contribute to that development. $[5.3,1902$; italics added]

[The meaning of a statement lies in the infinite future.] Accordingly, the pragmaticist does not make the summum bonum to consist in action, but makes it to consist in that process of evolution whereby the existent comes more and more to embody those generals [that we call] reasonable. In its higher stages, evolution takes place more and more largely through self-control, and this gives the pragmaticist a sort of justification for making the rational purport to be general. [5.433, 1905; boldface added]

Thus in the last stage of his philosophy Peirce found the meaning of symbols to consist in how they contribute to cosmic goal-achievement.

It is interesting that Peirce, the founder of pragmatism, began with a narrow goal, the improvement of human inquiry, and ended with a very broad goal, the extolling of human rational goal-seeking as a stage of cosmic goal-seeking or final causality. He then drew a moral implication, that humans should improve the skills that are relevant to rational goalseeking. What the pragmaticist

adores, if he is a good pragmaticist, is power; not the sham power of brute force, which, even in its own specialty of spoiling things, secures such slight results; but the creative power of reasonableness, which subdues all other powers, and rules over them with its sceptre, knowledge, and its globe, love. [5.520] 
I want to make two comments on this quotation, a short one concerning Peirce's last attempt to contribute to the goal of rational goal-seeking, and a longer one concerning his contrast between "the sham power of brute force" and "the creative power of reasonableness".

For Peirce, logic was always the preeminent tool for rationality, and in Stage IV he sought to improve its effectiveness by developing a triad of normative sciences: aesthetics as First, ethics as Second, and logic as Third. But he never worked out such a normative system, or even made clear what it would be like [8.255-257] (cf. Burks 1943). I think John Dewey's pragmatism can be viewed as achieving the goal Peirce had in mind. Dewey used aesthetics, ethics, logic, epistemology, and a theory of human nature normatively, and he encouraged the use of reason in education and in social and political matters, with considerable effect. In the process he contributed to the development of social psychology, which he regarded as a tool for human progress.

Finally, consider Peirce's contrast between the "sham power of brute force" and the "creative power of reasonableness". This is a basic example of his categories-brute force is Second, reason is above it as Third. Human desires, interests, specific goals, and volitions are Seconds; reasoning, inquiry, theorizing, and ideals are Thirds. Thirds are better than Seconds, and will ultimately dominate them. This asymmetry is part of Peirce's explanation of how evolution has generated humans from lower forms, and he took this achievement of evolution as empirical evidence for the asymmetry.

Peirce showed great insight in seeing that logic plays a basic role in evolution. But since he wrote on evolution, an alternative logic of evolution has become well-established, the Mendelian logic of genetic programs. This logic is discrete in contrast to the continuous logic of Synechism, and it gives a much better account of the progress of evolution than Peirce's logic. My own logical-mechanical theory of evolution is based on discrete Mendelian probabilistic logic rather than on Peirce's logic of continuity (Synechism) and his doctrine of final causality (Agapism) (Burks 1988a, 1988b; 1990, sec. 4; 1995).

Peirce held that the "sham power of brute force" competes with the "creative power of reasonableness", and that in the long run the latter will dominate. In contrast, Mendelian evolution treats the factors of desirevolition and experience-reason as independent interacting forces. These two factors constantly interact, with the desire factor setting the goals and observation and reason being employed in achieving them. This analysis yields a much better account of the enduring nature of evil and its relation to good than does Peirce's theory. This analysis is also the basis for a 
much better explanation of the tragedy of Peirce's own life: the extreme contrast between his great achievements and his deep frustrations. He had unbounded faith in the power of reason over desire, though desire often dominated reason in his own life.

We turn now to Peirce's views on God, which he sometimes connected to his pragmaticism [6.480-485, 6.502-503].

\section{SOME CONCEPTS OF GOD}

Charles Peirce (1839-1914) was a committed Christian. He was raised a New England Congregationalist, became an Episcopalian to marry Melusina Fay in 1862, and wrote considerably about religion in the last two stages of his thought. He was always religous in belief, and his religous beliefs played a very important role in his philosophizing.

Peirce was not religous in behavior - he did not go to church much, and he conspicuously violated the existing socio-religious rules of morality and proper conduct. He was not unique in this, of course, but he was more conspicuous than most men in his violations, much to his personal detriment and that of his two wives, Melusina and Juliette.

Nevertheless Peirce directed his philosophy toward reconciling religion with Darwinian evolution, and I think he gave the best reconciliation in existence at that time. Moreover, his theory of the origin of the universe explained creation as a gradual and scientifically understandable process, rather than as an ad hoc creation by divine fiat. Peirce very much wanted a regular position in a college or university so he could work with students and teach his views. Unfortunately, the people who controlled those positions did not understand his accomplishments, and he was not acceptable to them because of his behavior.

Though he was a Christian, Peirce incorporated aspects of other religions in his philosophy. He begins "The Law of Mind":

... tychism must give birth to an evolutionary cosmology, in which all the regularities of nature and of mind are regarded as products of growth, and to a Schelling-fashioned idealism which holds matter to be mere specialized and partially deadened mind. I may mention, for the benefit of those who are curious in studying mental biographies, that I was born and reared in the neighborhood of Concord - I mean in Cambridge - at the time when Emerson, Hedge, and their friends were disseminating the ideas that they had caught from Schelling, and Schelling from Plotinus, from Boehm, or from God knows what minds stricken with the monstrous mysticism of the East. But the atmosphere of Cambridge held many an antispetic against Concord transendentalism; and I am not conscious of having contracted any of that virus. Nevertheless, it is probable that some cultured bacilli, some benignant form of the disease was implanted in my soul, unawares, and that now, after long incubation, it comes to the surface, modified by mathematical conceptions and by training in physical investigations. (6.103) 
Concrete reasonableness, the goal state of Peirce's Tychism-SynechismAgapism is perhaps a rational version of the Hindu and Buddhist state of Nirvana.

The God of Christianity is a God of Love, and the last of Peirce's 189193 Monist papers is entitled "Evolutionary Love" [6.287-317]. In it Peirce develops his version of divine love - cosmic teleology - which he calls Agapism. He begins by preaching Saint John's doctrine that God is love.

Philosophy, when just escaping from its golden pupaskin, mythology, proclaimed the great evolutionary agency of the universe to be Love.

...

[Saint John said] "We know and have trusted the love which God hath in us. God is love." There is no logic in this, unless it means that God loves all men. [John had said earlier] "God is light and in him is no darkness at all." We are to understand, then, that as darkness is merely the defect of light, so hatred and evil are mere imperfect stages of [agape] and [agathos], love and loveliness.

Thus, the love that God is, is not a love of which hatred is the contrary; otherwise Satan would be a coordinate power; but it is a love which embraces hatred as an imperfect stage of it, an Anteros - yea, even needs hatred and hatefulness as its object. For self-love is no love; so if God's self is love, that which he loves must be defect of love; just as a luminary can light up only that which otherwise would be dark.

The movement of love is circular, at one and the same impulse projecting creations into independency and drawing them into harmony. This seems complicated when stated so; but it is fully summed up in the simple formula we call the Golden Rule... [This] says, Sacrifice your own perfection to the perfectionment of your neighbor.

...

It is not by dealing out cold justice to the circle of my ideas that I can make them grow, but by cherishing and tending them as I would the flowers in my garden. The philosophy we draw from John's gospel is that this is the way the mind develops; and as for the cosmos, only so far as it yet is mind, and so has life, is it capable of further evolution. Love, recognizing germs of loveliness in the hateful, gradually warms it into life and makes it lovely. That is the sort of evolution which every careful student of my essay "The Law of Mind" [the third paper of the series] must see that synechism calls for. [6.287-289]

This passage sounds as if Peirce wrote it in a state of ecstasy, and in any case it contradicts pragmatically Peirce's personal behavior.

Though Peirce was emotionally committed to religous belief (see Brent 1993), one of his aims (like that of his friend William James) was to provide an empirical and rational basis for both a concept of God and a belief that God as so-conceived is real. To evaluate his success I'll compare his views on God with the standard Christian alternatives. 
The concept of God is a difficult concept. God is infinite in reason, goodness, and power. But he cannot be infinite in the sense that some numbers and quantities are infinite, for there is no largest mathematical infinite. There is also the problem of the existence of evil. God is unlimited in his creative powers and his goodness, and yet the universe he created contains much evil. Evil is sometimes explained as the work of the devil, but then the relation of God to the devil is problematic.

We usually conceive of God by analogy with ourselves, but no one has ever constructed a logic for analogizing from the finite to the infinite. We think of creation on the model of a human creator - an artist creating a painting, a musician a concerto, a potter a vase. But these are all cases of a finite creator using available materials to form a finite object, whereas God is an infinite creator needing no materials.

My undergraduate philosophy teachers were both Methodist ministers with doctorates in philosophy. Theologically they were "personalists", holding that God is an infinite person who created the universe of space, time, and finite objects, including humans. God may intervene in the cosmos from time to time, miracles and mystical experiences being examples. Personalism is a form of theism.

Gottfried Leibniz's monadology was a highly organized theism. God is an infinite monad, who created infinitely many finite monads that constitute the created world. A human soul is a monad capable of consciousness, and the spatial and temporal organization of its experiences is subjective. God predetermined the experiential history of every monad so that all monads behave as if they are interacting, though none can influence any other. Thus each monad mirrors or models the universe to a degree corresponding to its apparent interactions with other monads. A human's concept of God is a specific example of this mirroring, and whether or not a person believes in God is predetermined by God. Leibniz's pre-determinism is, of course, the extreme opposite of Peirce's Tychism.

Both personalism and Leibniz's monadology view God as one substance and the world he created (the world we know) as another substance or complex of substances. This underlying metaphysics is characteristic of theism. In contrast, pantheism treats God and the universe we know as one substance. "God is all, and all is God". The difference between God and the universe then becomes the difference between fundamental aspects of God, a difference in global properties rather than in substances, or a difference between the whole and its parts: God is eternal and infinite, while each particular thing is a transient part of God. Peirce was a pantheist, but before presenting his version I'll describe some previous forms of pantheism. 
Emanationism is an early form of pantheism, in which creation takes the form of a series of emanations from God. God first emanates the transcendent realm of intellect and Platonic ideas, then human minds and souls, and finally the lowest forms of reality: space-time, animals, plants, and plain matter. Each new level is lower than the preceeding level in both degree of reality and degree of perfection. Indeed, in this theology, reality and perfection are intrinsically correlated, for successive emanations obey the metaphysical principle that a cause must have as much reality and value as its effect. Most standard arguments for God's existence flow from this principle (Burks 1988b, p. 337).

We can illustrate the difference between theism and pantheism by comparing the views of Descartes and Spinoza. In Descartes' theistic metaphysics, God is the supreme substance who created a world of two interacting kinds of substance: mental and material. Spinoza replaced this structure by a single substance having God (natura naturans) and Nature (natural naturata) as two basic aspects. As he expressed it, he divided

... the whole of Nature into Natura naturans and Natura naturata. By Natura naturans we understand a being that we conceive clearly and distinctly through itself, without needing anything other than itself ..., that is, God...

We shall divide Natura naturata in two: a universal and a particular. The universal consists in all those modes which depend on God immediately ... The particular consists in all those singular things which are produced by the universal modes. So Natura naturata requires some substances in order to be conceived properly.

But as far as the thing itself is concerned, I think I have demonstrated clearly and evidently enough that the intellect, though infinite, pertains to Natura naturata, not to Natura naturans.

By God I understand a being absolutely infinite, that is, a substance consisting of an infinity of attributes, of which each one expresses an eternal and infinite essence.

Whatever is, is in God, and nothing can be or be conceived without God.

(Curley 1994, pp. 57-8, 81, 85, 94)

Georg Hegel was the main founder of absolute idealism, and he was a pantheist. We'll see in a moment that Peirce's pantheism was influenced by his.

\section{PEIRCE'S CONCEPT OF GOD}

Peirce, as a pantheist, thought God and the cosmos constituted one substance. To introduce his views we will trace the philosophic theme that runs through all four stages of his thought: the cosmos is an infinite semi- 
otic goal-directed evolutionary process that converges on the good and the real.

In Stage I he expressed it:

... every thought must be interpreted in another, [and] all thought is in signs ... [5.253]

... MAN IS A SIGN ....... the man is the thought. [5.314]

... reality depends on the ultimate decision of the community. ... [5.316]

In Stage II he said

... the ideas of truth and falsehood, in their full development appertain exclusively to the scientific method of settling opinion. [5.406]

The opinion which is fated to be ultimately agreed to by all who investigate, is what we mean by the truth, and the object represented in this opinion is the real. [5.407]

Stages I and II of Peirce's intellectual evolution form a unit in that both are about human semiotic evolution. Stages III and IV form a unit in that both are about cosmic evolution.

In Stage III Peirce found cosmic evolution to be a hierarchical process with three aspects:

- Tychism, the doctrine that probabilistic laws are basic, and deterministic laws are limiting cases of these

- Synechism, the doctrine that reality is a continuous evolutionary process, moving from a state of complete randomness toward perfect regularity

- Agapism, the doctrine that cosmic evolution is goal-directed.

... the universe is a vast representamen, a great symbol of God's purpose, working out its conclusions in living realities.

The Universe as an argument is necessarily a great work of art, a great poem ...

The evolutionary process is, therefore, not a mere evolution of the existing universe, but rather a process by which the very Platonic forms themselves have become or are becoming developed. [6.194]

In Stage IV Peirce reformulated and renamed his pragmatism:

[According to pragmaticism] the only ultimate good is ... to further the development of concrete reasonableness, so that the meaning of the concept does not lie in any individual reactions at all, but in the manner in which those reactions contribute to that development. $[5.3,1902$; italics added $]$

Human purposiveness is only a special case of final causality or cosmic purposiveness: 
It is . . a widespread error to think that a "final cause" is necessarily a purpose. A purpose is merely that form of final cause which is most familiar to our experience. [1.211; cf. 8.272]

... ideas are not all mere creations of this or that mind, but on the contrary have a power of finding or creating their vehicles, and having found them, of conferring upon them the ability to transform the face of the earth. [1.217]

The evolutionary process is, therefore, not a mere evolution of the existing universe, but rather a process by which the very Platonic forms themselves have become or are becoming developed. [6.194]

Peirce's evolutionary pragmatic idealism was a radically new form of pantheism. He replaced the theist's idea of a "one-shot" creation of the world by the gradual creation of the world through the evolutionary process of Tychism-Synechism-Agapism. He thought of cosmic evolution as a divine learning process. Chance, continuity, and cosmic purposes are all aspects of God, and we humans are parts of this infinite evolutionary divine system.

Analogy suggests that the laws of nature are ideas or resolutions in the mind of some vast consciousness, who, whether supreme or subordinate, is a Diety relative to us. I do not approve of mixing up Religion and Philosophy; but as a purely philosophical hypothesis, that has the advantage of being supported by analogy. Yet I cannot clearly see that beyond that support to the imagination it is of any particular scientific service.... [5.107]

The word "God", so "capitalized" (as we Americans say), is the definable proper name, signifying Ens necessarium; in my belief Really creator of all three Universes of Experience. [6.452]

In an unpublished paper, "Answers to Questions Concerning My Belief in God" (6.494-521, c. 1906), Peirce appealed to instinct or faith (a form of Firstness):

... the discoveries of science, their enabling us to predict what will be the course of nature, is proof conclusive that, though we cannot think any thought of God's, we can catch a fragment of His Thought, as it were.

Now such being the pragmaticist's answer to the question what he means by the word "God", the question whether there really is such a being is the question whether all physical science is merely the figment - the arbitrary figment - of the students of nature, and further whether the one lesson the Gautama Boodha [sic], Confucius, Socrates, and all who from any point of view have had their ways of conduct determined by meditation upon the physico-psychical universe, be only their arbitrary notion or be the Truth behind the appearances which the frivolous man does not think of; and whether the superhuman courage which such contemplation has conferred upon priests who go to pass their lives with lepers and refuse all offers of rescue is mere silly fanaticism, the passion of a baby, or 
whether it is strength derived from the power of truth. Now the only guide to the answer to this question lies in the power of the passion of love which more or less overmasters every agnostic scientist and everybody who seriously and deeply considers the universe. But whatever there may be of argument in all this is as nothing, the merest nothing, in comparison to its force as an appeal to one's own instinct, which is to argument what substance is to shadow, what bed-rock is to the built foundations of a cathedral. [6.502-505]

When asked "Do you believe this Supreme Being to have been the creator of the universe?" he answered "Not so much to have been as to be now creating the universe", referred to his Monist articles, and said that "all reality is due to the creative power of God" [6.505].

Peirce's evolutionary pragmatic idealism is an evolutionary form of pantheism that operates in the opposite direction from emanationism and Spinozism. Whereas the latter theologies proceed from the highest level (God) on down through successively lower levels, Peirce's cosmic evolutionism begins at the simplest level of a random chaos of feelings and gradually improves under the guidance of final causality toward an infinite limit of perfection. Thus Peirce's pantheism is emanationism "turned upside down".

Both emanationism and Peirce's evolutionism hold that reality and perfection are intrinsically related. Successive emanations obey the metaphysical principle that a cause must have at least as much reality and value as its effect. In Peirce's evolutionism the distinction between good and evil only arises when the cosmos becomes organized, and as it becomes better organized the cosmos becomes better. Emanationism and Peirceanism do agree that evil is a lack of good.

We explained Peirce's logical principle "Do not block the road of inquiry" in the section on Tychism, and showed how it led to the doctrine that all laws are to some degree probabilistic. His evolutionary pantheism reflects the same principle, for it gives a gradual account of creation rather than a one-shot account. Peirce was the first to develop a probabilistic account of the evolutionary origin of the cosmos and of biological evolution, and then make it the basis for a concept of God.

$$
* * *
$$

Since pantheism identifies God with the universe, it thereby includes in God the lower levels of reality that theism treats as non-divine. But the pantheist recognizes differences among levels or aspects, and identifies God with the highest level or aspect of the universe. For Peirce this consisted of the triple cosmic logic of Chance, Continuity, and Final Causality. Hegel identified God with the highest operation of dialectic, the iterated suc- 
cession of Thesis, Antithesis, and Synthesis. Thus both Peirce and Hegel held that REASON is the highest aspect of God. And they both regarded religious institutions as representing God in an imaginative, story-telling, and aesthetic way. [In contrast, the materialist George Santayana kept only these semiotic aspects of religion.]

Peirce told more about his concept of God when he compared his view with Hegel's:

... my philosophy resuscitates Hegel, though in a strange costume. [1.42]

This "strangeness" is the very big difference between Peirce's cosmic evolutionary logic and Hegel's dialectic logic of the Absolute. We showed earlier that Tychism, Synechism, and Agapism are cosmic generalizations of abduction, induction, and deduction, respectively. Peirce's "costume" is fuller than Hegel's, because Hegel had nothing analogous to abduction and induction.

In Stage IV of his thought, Peirce modified and renamed his pragmatism, calling it "pragmaticism" to accord with his extension of pragmatic rationality to cosmic rationality, what he called "the development of concrete reasonableness". He then stated his relation to Hegel in this way:

The truth is that pragmaticism is closely allied to the Hegelian absolute idealism, from which, however, it is sundered by its vigorous denial that the third category (which Hegel degrades to a mere stage of thinking) suffices to make the world, or is even so much as self-sufficient. (5.436)

Here is another quotation in which Peirce criticizes Hegel for not having the equivalents of cosmic abduction and induction.

[Hegel says that] the whole universe and every feature of it, however minute, is rational, and was constrained to be as it is by the logic of events, so that there is no principle of action in the universe but reason. But I reply, this line of thought, though it begins rightly, is not exact. A logical slip is committed; and the conclusion reached is manifestly at variance with observation. It is true that the whole universe and every feature of it must be regarded as rational, that is as brought about by the logic of events. But it does not follow that it is constrained to be as it is by the logic of events; for the logic of evolution and of life need not be supposed to be of that wooden kind that absolutely constrains a given conclusion. [By the "wooden kind" Peirce is referring to the limited scope of thesis-antithesis-synthesis.] The logic may be that of the inductive or hypothetic [i.e., abductive] inference.

This may-be is at once converted into must-be when we reflect that among the facts to be accounted for are such as that, for example, red things look red and not blue, and vice versa. It is obvious that that cannot be a necessary consequence of abstract being.

The effect of this error of Hegel is that he is forced to deny [the] fundamental character of two elements of experience which cannot result from deductive logic [but require abduction and induction]. [6.218]

Peirce's reference to deductive logic in the last sentence of this quotation needs explanation, for Hegel's logic was not deductive, but dialectical. 
The logic of thesis-antithesis- synthesis is foundationally different from deduction. In a deductive logic a contradiction yields everything. Thus for any proposition $q$ :

$$
\begin{aligned}
& p \text { yields } p \vee q \\
& p \vee q \text { and } \sim p \text { yield } q \\
& \text { hence, } p \& \sim p \text { yields } q .
\end{aligned}
$$

The idea of a contradiction is much more complicated in Hegelian logic. For in dialectic the contradiction between a thesis and its antithesis yields a synthesis, which combines the best elements of both thesis and antithesis. Nevertheless, before Hegel's time "logic" meant "deductive logic", and Hegel's dialectic logic is obviously more like deduction than like induction or abduction.

\section{CONCLUSION}

Peirce stated the guiding principle of his life-long philosophical quest when he was a young man:

... my language is the sum total of myself; for the man is the thought.

It is hard for man to understand this, because he persists in identifying himself with his will, his power over the animal organism ... .

This is man,

"... proud man,

Most ignorant of what he's most assured,

His glassy essence".

$[5.314-317,1868]$

Man is a sign in an infinite semiotic and inferential process - that is his glassy essence.

There are two distinct themes in historical idealism, one based on IDEALS and the other based on IDEAS, and they don't always go together. The first bases philosophy on human reason and attributes a lower status to human will and desire, believing that in the long run reason and ideals will prevail over evil. The second bases philosophy on human experiences, such as feelings or sense experiences. Peirce combined both traditions with his Agapism and his panpsychism.

Humans generally hold that they and their organizations are the most advanced products of evolution. Hence it is natural for them to use their experiences as an analogical base for understanding the nature of divinity. I think Peirce did this when analogizing from his own abductive and inductive inferences and his particular concept of the infinitesimal to the 
divine logics of Tychism and Synechism; he also did this when analogizing from his own experiences of planned rational goal- seeking to Agapism. It would therefore be natural for him to analogize from human consciousness to some kind of consciousness appropriate to God, and he did this in one of his Harvard Lectures:

Analogy suggests that the laws of nature are ideas or resolutions in the mind of some vast consciousness, who, whether supreme or subordinate, is a Diety relative to us. ... that [thesis] has the advantage of being supported by analogy. [5.107, 1903]

On the other hand, a few years later he said the opposite:

Since God, in His essential character of Ens necessarium, is a disembodied spirit, and since there is strong reason to hold what we call consciousness is either merely the general sensation of the brain or some part of it, or at all events some visceral or bodily sensation, God probably has no consciousness. [6.489, 1908, boldface added]

But in "Man's Glassy Essence" he had generalized from human consciousness to corporate consciousness, and corporations don't have biological brains.

The consciousness of a general idea has a certain "unity of the ego", in it, which is identical when it passes from one mind to another. It is, therefore, quite analogous to a person; and, indeed, a person is only a particular kind of general idea. Long ago, in the Journal of Speculative Philosophy (Vol. II, p. 156), I pointed out that a person is nothing but a symbol involving a general idea...

All that is necessary, upon this theory, to the existence of a person is that the feelings out of which he is constructed should be in close enough connection to influence one another. Here we can draw a consequence which it may be possible to submit to experimental test. Namely, if this be the case, there should be something like personal consciousness in bodies of men who are in intimate and intensely sympathetic communion. ... Esprit de corps national sentiment, sym-pathy, are no mere metaphors. None of us can fully realize what the minds of corporations are, any more than one of my brain cells can know what the whole brain is thinking. But the law of mind clearly points to the existence of such personalities ... [6.270-271, 1892]

These statements about God and consciousness are inconsistent, so I will conclude by suggesting what Peirce might have consistently said on the subject.

We humans are the highest product of evolution so far, and our consciousplanned-rational goal-seeking is a unique ability. This ability is our chief instrument in the pursuit of concrete reasonableness, both as individuals and in communities that pursue common ideals.

God is the creative power in evolution. Consciousness is a human means for contributing to the growth of concrete reasonableness. As evolution continues, it will develop more and more advanced means for the growth of concrete reasonableness. This strand in evolution is God's consciousness. 
Reality is a single complex, hierarchical, dynamic system. It is an infinite evolutionary developmental process that starts from nothing and progresses gradually toward greater complexity, rationality, and value. God is the creative, rational, teleological aspect of reality, the highest level of the system.

\section{NOTE}

* I wish to thank Don Roberts for his many helpful comments and Peirce references, Edwin Curley for his suggestions, and Michael Cohen for pointing out the need of a section explaining Peirce's panpsychic Firsts. I have profited from discussions with my wife, Alice, as well as from her editorial assistance.

\section{REFERENCES}

Brent, Joseph: 1993, Charles Sanders Peirce-A Life, Indiana University Press, Bloomington.

Burks, Alice R. and Arthur W. Burks: 1988a, The First Electronic Computer: The Atanasoff Story, University of Michigan Press, Ann Arbor.

Burks, Arthur W. and Alice R. Burks: 1988b, 'The History of Early Computer Switching', Grazer Philosophische Studien 32, 3-36.

Burks, Arthur W.: 1943, 'Peirce's Conception of Logic as a Normative Science', The Philosophical Review 2, 383-88.

Burks, Arthur W.: 1946a, 'Laws of Nature and Reasonableness of Regret', Mind 55, 170-72.

Burks, Arthur W.: 1946b., 'Peirce's Theory of Abduction', Philosophy of Science 13, 301-06.

Burks, Arthur W.: 1951a, 'The Logic of Causal Propositions', Mind 60, 363-382.

Burks, Arthur W.: 1951b, 'Introduction to Peirce Selections', in Max Fisch (ed.), Classic American Philosophers, Appleton-Century-Crofts, New York, pp. 41-53. The 1966 printing has an additional note on p. 113.

Burks, Arthur W.: 1964, 'Peirce's Two Theories of Probability', in Edward C. Moore and Richard S. Robin (eds), Studies in the Philosophy of Charles Sanders Peirce, University of Massachusets Press, Amherst, pp. 141-50.

Burks, Arthur W.: 1972-73, 'Logic, Computers, and Men', Proceedings and Addresses of the American Philosophical Association 46, 39-57

Burks, Arthur W.: 1977, Chance, Cause, Reason-An Inquiry into the Nature of Scientific Evidence, University of Chicago Press, Chicago. Paperback, 1979.

Burks, Arthur W.: 1980, 'Man: Sign, or Algorithm? A Rhetorical Analysis of Peirce's Semiotics', Transactions of the Charles S. Peirce Society 16, $279-92$.

Burks, Arthur W.: 1986, Robots and Free Minds, College of Literature, Science, and the Arts, University of Michigan, Ann Arbor. 
Burks, Arthur W.: 1988a, 'The Logic of Evolution and the Reduction of Coherent-Holistic Systems to Hierarchical-Feedback Systems', in William Harper and Bryan Skyrms (eds.), Causation in Decision, Belief, Change and Statistics, Kluwer Academic Publishers, Dordrecht.

Burks, Arthur W.: 1988b, 'Teleology and Logical Mechanism', Synthese 6, 333-70.

Burks, Arthur W.: 1990, 'The Philosophy of Logical Mechanism: My Replies to My Critics', pp. 349-531 of Salmon 1990.

Burks, Arthur W.: 1995, 'Logic, Learning, and Creativity in Evolution', in Don Roberts, Nathan Houser and James van Evra (eds.), Studies in the Logic of Charles S. Peirce, Indiana University Press, Bloomington (to be published).

Curley, Edwin, editor and translator: 1994, A Spinoza Reader-The Ethics and Other Works - Benedict de Spinoza. Princeton University Press, Princeton.

Kant, Immanuel: 1781, 1787, Kritik der reinen Vernunft. English translation by N. K. Smith (1933), Critique of Pure Reason, Macmillan, London.

Moore, Edward C. and Arthur Burks: 1992, "Three Notes on the Editing of the Works of Charles S. Peirce', Transactions of the Charles S. Peirce Society, 28, 83-106.

Peirce, Charles S.: 1887, 'Logical Machines', The American Journal of Psychology, 1, 165-70.

Peirce, Charles S: Collected Papers of Charles Sanders Peirce, Vols. 1-6, 1931-35, edited by Charles Hartshorne and Paul Weiss; Vols. 7-8, 1958, edited by Arthur W. Burks; Vol. 8 contains a bibliography of Peirce's published works, Harvard University Press, Cambridge. Peirce citations in this paper are to volume and paragraph: e.g., 7.361 refers to vol. 7 , par. 361 .

Peirce, Charles S. Writings of Charles S. Peirce-A Chronological Edition, An edition of perhaps 30 volumes is in progress, of which 5 volumes have appeared, 1982 on. Edward Moore was the founding editor; the chief editors have been Max Fisch, Christian Kloesel, Nathan Houser, and Don Roberts, Indiana University Press, Bloomington.

Roberts, Don D.: 1973, The Existential Graphs of Charles S. Peirce, Mouton, The Hague.

Salmon, Merrilee H. (ed.): 1990, The Philosophy of Logical Mechanism - Essays in Honor of Arthur W. Burks, with his responses and a bibliography of his works, Kluwer Academic Publishers, Dordrecht/Boston/London.

Weiss, Paul and Arthur Burks: 1945, 'Peirce's Sixty-Six Signs', The Journal of Philosophy 42, 383-88.

Wiener, Philip: 1949, Evolution and the Founders of Pragmatism, Harvard University Press, Cambridge.

University of Michigan

and

Indiana University - Purdue University at Indianapolis 